\title{
VI. ZEDEN EN GEWOONTEN EN HET DAARMEDE SAMENHANGEND ADATRECHT VAN HET MINAHASSISCHE VOLK. ${ }^{1}$ )
}

\author{
DOOR \\ L. ADAM, \\ CONTROLEUR BINNENL. BEST.
}

Wie slechts een oppervlakkig denkbeeld heeft van het huiselijk en maatschappelijk leven van het Minahassische volk, weet reeds hoezeer dat onder de stammen van dit kleine volkje nog uiteenloopt. Er bestaat nog geen voldoende eenheid onder die verschillende groepen. Onder den rook van Menado, reeds aan de overzijde van de rivier en op 6 K.M. afstand daarvan leeft een volkje, dat nog steeds zijne groote zelfstandigheid heeft behouden en weinig verwantschap toont met de andere volksgroepen van de Minahassa, ik bedoel n.l. de Bantikkers. Dan heeft men de Tomboeloe', die de voormalige districten Menado, Tombariri en Tomohon-Sarongsong bewonen; welk een verschil ziet men bijv. nog in de zeden en gewoonten van de menschen van Tombariri en Tomohon, ja zelfs van Tomohon en Sarongsong. En hetzelfde kan gezegd worden van de Tontèmboan, die Langoan, Sonder, Kawangkòan, Amoerang en Tompasò' bewonen (zoo wijken bijv. de Langoansche gebruiken af van de Kawangkòansche en Sondersche) en van de Tonséa' (bijv. tusschen de bewoners van Maoembi en Ajermadidi en omgeving) en van de Toulour (tusschen de bewoners van Ka'kas en Tondano, ja zelfs tusschen Ka'kas en Rembokken. De Ratahanners hebben weer andere zeden en gewoonten en opvattingen dan de drie bovengenoemde groote Minahassische stammen

1) Dit artikel is gecorrigeerd door dr. N. Adriani.

Voor eenige kwesties op ethnologisoh gebied mocht ik de meest uitvoerige inlichtingen krijgen van mr. F. D. E. van Ossenbruggen.

Aan deze twee geleerden en ook aan de vele Minahassers, die mij bij het verzamelen van gegevens behulpzaam waren betuig ik hierbij nogmaals mijn hartelijken dank. 
en \pm 15 K.M. van Ratahan in Bélang leeft een volkje, de Pon osakanners, de eenige Mohammedaansche Minahassers, die eene afdeeling vormen van het Mongondousche volk, en bovendien in hunne sadat kebiasaan» Islamsche inzettingen hebben. En 15 K.M. westelijk van Ratahan wonen de Tonsini, in het kleine districtje Tonsáwang, waarvan prof. Van Vollenhoven veronderstelt (zie Het Adatrecht van Nederlandsch-Indië deel I blz. 327) - en m.i. ten rechte - dat het "als een eigen rechtsgouw; is aan te merken.

Men begrijpt hoe moeilijk het is deze zoo uiteenloopende zeden en gewoonten en rechtsopvattingen te kennen en te beschrijven. De schrijver heeft zich daarom zooveel mogelijk bepaald tot de algemeen bekende gebruiken en rechten en zich niet verdiept in de kleine plaatselijke verschillen.

Ook in ander opzicht is er onvolledigheid in dit hoofdstuk. De lezers-ethnologen zouden wellicht graag wat meer materiaal gezien hebben uit den nog zoo ongerepten heidenschen tijd en ik moet hun bekennen dat mij de lust daartoe herhaaldelijk heeft bekropen, maar ook hier de beperktheid der ruimte mij dwong me te bepalen tot den huidigen toestand; slechts hier en daar veroorloofde ik me afdwalingen. Evenmin kon ik veel folkloristisch materiaal op het gebied buiten de door mij behandelde onderwerpen, zooals op het gebied van landbouw, veeteelt, visscherij enz. behandelen.

$\mathrm{Nu}$ valt niet te ontkennen, dat in ander opzicht mijne taak aanmerkelijk werd verlicht en wel door de reusachtig uitgebreide litteratuur die omtrent de oude adat geschreven is. In dit verband dienen de namen, die wij voortdurend in den tekst zullen tegenkomen; met eêre genoemd te worden: Dr. Johann Gerard Friedrich Riedel in Tondano geboren, begon in 1855 zijn bestuursloopbaan in de. Minahassa en eindigde die met resident van Ambon, schreef een groot aantal artikelen op gebied van taal-, land- en volkenkunde der Minahassa, die, hoewel zij met groote voorzichtigheid gebruikt dienen te worden, toch van groot pionierswerk getuigen, - overleed in 1911, 80 jaar oud; Professór Dr. George Alexander Wilken in 1847 te Menado geboren en evenals de vorengenoemde in het begin van zijn loopbaan bestuursambtenaar, o, a. in Ratahan, waar hij later in druk be werkte artikelen over de: Minahassa schreef (1872-1875), "in 1885 tot hougleeraar benoemd, een geleerde wiens vermaardheid 
nu nog tot verre over onze landsgrenzen strekt ${ }^{1}$ ); de Zendeling Johannes Albert Traugott Schwarz, geboren 22 Juni 1836 te Langoan, overleden te Soerabaja, in 1918, één der weinige Evangeliedienaren in de Minahassa die inzag, dat talenkennis voor zijn werk van onschatbaren dienst was. Een bescheiden, groot man, die maar al te weinig van zijne kennis heeft gepubliceerd; in samenwerking met Dr. Adriani en Mevr. Adriani zijn echter van 1902-1905 geschriften samengesteld omtrent het Tontèmboansch, die in 1907 en 1908 het licht zagen ${ }^{2}$ ).

Wat deze drie groote mannen gepresteerd hebben, beseft men eerst recht, wanneer men weet hoe beperkt hunne wetenschappelijke vooropleiding was, en hoezeer de wetenschap der ethnologie gedurende hunne onderzoekingen nog in hare windselen lag. Hunne geschriften, welke ik straks nog telkens zal aanhalen, waren voor mij de grondslag, waarop ik mijne onderzoekingen en inlichtingen van de huidige adat en het gewoonterecht kon beginnen.

Van onschatbaren dienst waren mij daarbij ook de rapporten en artikelen van - en hier zij dan met niet minder eer naast de bovengenoemde trits van geleerde vorschers een vierde genoemd Mr. J. H. Carpentier Alting, van 1897-1900 voorzitter van den landraad te Menadc, later hoogleeraar te Leiden, daarna president van het Hooggerechtshof en lid van den Raad van NederlandschIndië. Het ontstaan van zijne "Regeling van het privaatrecht voor de Inlandsche bevolking in de Minahassa-districten der residentie Menado ${ }^{3}$ ) is voor de geschiedenis van het adatrecht in den Indischen Archipel in het algemeen en van dat van de Minahassa in het bijzonder niet zonder beteekenis. - De Minister

1) Zie over hem het Levensbericht in deel I van de door Mr. F. D. E. van Ossenbruggen uitgegeven Verspreide geschriften van dezen grooten ethnoloog.

2) Zie voor zijne levensbeschrijving en zijne talenstudie: Mededeelingen van het Nederlandsche Zendeling-genootschap 62e deel $2^{\mathrm{e}}$ stuk; Maandblad der Samenwerkende Zendingeorporaties afl. 5; Bijdragen van het Kon. Instituut deel 74; Encyclopaedie van Ned. Indië $2 \cdot$ druk i. v. Schwarz.

s) Vijf deelen, alle gedrukt met machtiging der Regeering. Deel I (A. Over afstamming. B. Over adoptie); deel II (Huwelijk. Ontwerp en nota van toelichting); daarop volgt eerste gedeelte eerste stuk (Burgerlijke stand; huwelijk; afstamming; adoptie); eerste gedeelte tweede stuk (Burgerlijke stand, huwelijk, afstamming, adoptie, Ontwerpen); eerste gedeelte derde stuk (Burgerlijke stand; huwelijk; afstamming; adoptie; toelichtingen op de ontwerpen); en tweede gedeelte (voogdij, inlandsch notariaat). 
van Koloniën Cremer (1897-1901) wilde aan de onzekerheid van het adatrecht in Indië een einde maken door plaatselijke codificatie van dat recht, te beginnen met de streken waar de bevolking grootendeels uit Christenen bestond. In 1901 werd toen aan Mr. J. H. Carpentier Alting de opdracht verleend, om regelingen te ontwerpen van den rechtstoestand der Inlandsche bevolking in de Minahassa ten aanzien van het privaatrecht en het voorbereiden van zoodanige regeling voor andere gewesten, in het bijzonder Ambon en Ternate. - Reeds tevoren in 1895 had de resident Jellesma eene commissie van aanzienlijke Inlanders aangewezen om het in de Minahassa geldend gewoonterecht te beschrijven. Hun rapport is gepubliceerd in Adatrechtbundel III blz. 4 e.v. Ook de door Mr. Carpentier Alting geschreven verslagen, die een schat van gegevens bevatten op het gebied van het Minahassisch adatrecht zijn, zooals gezegd, gepubliceerd ${ }^{\mathbf{1}}$ ), doch helaas! moest zijn werk onvoltooid blijven. Intusschen toch kwam in het moederland aan het bewind de minister Idenburg, die een sterk voorstander was van unificatie van het recht en het onderzoek Carpentier Alting dus onmiddellijk deed staken. Geheel verdwenen was de kans op codificatie echter niet. In 1915 kwam de adjunct-adviseur mr. J. C. Kielstra in de Minahassa met de opdracht om het adatrecht onder de ChristenInlanders op schrift te stellen. Op 19 en 20 April van genoemd jaar besprak hij met verscheidene hoofden en Inlandsche godsdienstleeraars te Ka'kas eene ontworpen codificatie. Tot nogtoe is omtrent de resultaten daarvan niets bekend geworden. In 1918 ging wederom een stem, thans uit den Volksraad, op, om codificatie, thans van het lid van dat college A. L. Wawo Runtu. Het antwoord van den Directeur van Justitie leert ons de huidige Regeeringsopvatting ten aanzien van dit onderwerp: geen vastlegging in geschreven wetten van plaatselijk adatrecht, maar ééne voor geheel Indië geldende regeling van het Inlandsch privaatrecht met verwijzingen naar plaatselijk gebruik wanneer bepaalde instellingen in Indië onderling afwijken. De heer Wawo Runtu trok daarop zijn amendement in. ${ }^{2}$ ) Helaas! Het

1) Men leze de critiek hierop van Mr. I. A. Nederburgh in het Recht van Nederlandsch-Indië deel $81 \mathrm{blz} .318$ e. v. en Mr. F. C. Hekmeyer in Indische Gids 1904 deel II blz. 1026 e. v.

2) Zie Handelingen van den Volksraad, tweede gewone zitting $1918 \mathrm{blz}$. $264-267$. 
toekomstige Algemeen Burgerlijk Wetboek zal in geen geval de bestaande rechtsonzekerheid wegnemen, want verwijzing naar het plaatselijk gebruik opent wederom de mogelijkheid van velerlei uitlegging. Want het adatrecht is in dit land in dat stadium gekomen waarop een ieder het naar zijn eigen belang interpreteert, hetgeen den Inlandschen rechter meestal tureluursch makkt. - Het zou mij niet verbazen, dat wanneer den Minahassaraad in deze om zijn advies werd gevraagd het een parig antwoord zou luiden: codificatie: In het ondervolgende heb ik nog gelegenheid te over te betoogen hoe weinig de Regeeringsbeslissing in het algemeen belang van den rechtstoestand in de Minahassa is.

Het wordt nu tijd, dat ik aan mijn eigenlijke onderwerp begin. Beschreven zullen alleen worden huisvesting, voeding, huwelijk, zwangerschap, geboorte, naamgeving, adoptie, animistische bestrijding van ziekten, dood, lijkbezorging, grondbezit en ten slotte het mapaloes.

Moge de onvolledigheid van mijn opstel eene; aanleiding zijn, voor Minahassers vooral, om hunne eigen volkskunde te bestudeeren en die, evenals de heer P. A. Mandagie van zijn Bantiksch volk heeft gedaan, in tijdschriften te publiceeren. ${ }^{1}$ ).

Huisvesting en voeding.

Alvorens wij een blik werpen op het huiselijk en maatschappelijk leven van den Minahasser, dienen wij ons een goed beeld te vormen hoe het volk gehuisvest is en wat zijn dagelijksch voedsel is.

De oud-Minahassische woningen stonden op zeer hooge palen en waren juist om die reden niet bestand tegen de hevige

1) Waar in den ondervolgenden tekst (Mal,) staat geschreven beteekent dit het z.g. Moluksch Maleisch.

Tb. beteekent Tomboeloe'sch.

Tt. $n$ Tontèmboansch.

Ts. " Tonséa'sch.

Td. $n$ Tondanosch.

Bt. . n Bantiksch.

Rat. " Ratahansch.

Pon. $n$ Ponosakansch.

Tons, $n$ Tonsawangsch. 
aardbevingen van Februari 1845, toen duizenden woningen instortten. Men had echter eertijds voor die hoog boven den grond staande paalwoningen een motief. In den grooten onderlingen stammenkrijg immers was het geraden zelfs binnen de gepalisadeerde negorij ook de woning te beveiligen tegen verrassende sluipaanvallen van den vijand. De trap (a'ran Tb., raran $\mathrm{Tt}$.), die toegang tot het huis gaf kon dan ook opgehaald worden en werd slechts nedergelaten wanneer men een huis- of negorijgenoot wilde uit- of inlaten.

Schwarz geeft ons in zijn opstel "Manewas" (een heidensch huisoffer) in Mededeelingen vanwege het Nederl. Zendelinggenootschap deel 47 blz. 122 in eene duidelijke teekening een goed beeld van een oud-Tontèmboansche woning.

Eene huidige woning, zooals men die bijna over de geheele Minahassa ziet, ofschoon natuurlijk afwijkingen voorkomen, vertoont weinig bijzondere kenmerken. Rijke menschen hebben meer kamers, trekken het huis op uit mooier materiaal, armen hebben soms heelemaal geen kamers, alleen twee "galerijen, terwijl alles gemaakt is van bamboe en niboeng, en vaak niet eens op palen staat.

Men onderscheidt de woningen (in alle talen walé of balé genoemd) nog in huizen op hooge palen of steenen pilaren staande, in het $\mathrm{Tb}$. genoemd walé meito'tol en huizen, die lager op den grond staan en slechts op groote steenen rusten, wal'é miwangin (Tb.). Bij de eerste rusten op de palen, to mbol (Tb.) of ari'i (Tt. en Tb.) groote stevige balken, waarop weer de eigenlijke vloerbalken steunen. Gegoeden hebben planken vloeren, de anderen slechts vloeren van platgeslagen niboeng, woka of bamboe. In Tonséa', vooral tusschen Ajermadidi en Kéma, de z.g. "Langstraat», waar men de mooiste woningen ziet, bestaan zelfs huizen met mooie steenen vloeren in de voorgalerij, of geheel van steen opgetrokken. Daartoe gebruikt men riviersteenen met cement, want de kunst van het steenbakken verstaat de Minahasser niet. Daarom zijn de wanden over het algemeen van hetzelfde materiaal vervaardigd als de vloer.

$\mathrm{Bij}$ de tweede bovengenoemde soort van woningen rust de vloer eigenlijk dadelijk op de balken, die op de palen steunen. Het onderstel van de walé meito'tol is dus veel sterker. Deze huizen hebben ook meer ruimte onder den vloer op den beganen grond. De Europeanen noemen die ruimte de kòlòng 
(Mal.); daar bergt men de landbouwgereedschappen, het rijststampblok (l esoeng Tt., Td., Ts., Tb., of lisoeng Bt., Rat., Pon.) voertuigen, enz.

De bedekking van het dak (atep in nagenoeg alle talen) is gewoonlijk van het blad van den sagopalm gemaakt (roe mbia Tt., Tb.).

De waaiervormige takken van dezen boom die uit den grond of aan den stam opschieten, zijn ongeveer 15 à 20 voet lang en hebben aan weerszijden van de ribben bladeren van 4-5 voet lengte en $3-3 \frac{1}{2}$ duim breedte, waarvan er ruim 100 aan een tak kunnen zitten. "Die bladeren", schrijft Graafland in zijn boek De Minahassa, "worden afgesneden, om riet gevouwen en de beide einden van gelijke lengte over eene dunne, smalle lat van gespleten bamboe of ook wel riet, met gespleten rottan, ter dikte van gewoon bindtouw, te zamen genaaid. Dat eind bamboe of riet is gewoonlijk p. m. zes voet lang en bevat ongeveer 40 bladeren, die half over elkander zijn gelegd». Zulk een strook is één faras katoe (Mal.). Deze faras' worden van beneden af, schubsgewijze over elkander op het dak gelegd. Voor een gewoon huis heeft men er ongeveer drie tot vijfhonderd, voor grootere huizen vier tot acht duizend. De katoe-dakbedekking is deugdelijker dan de alang-alang-bedekking, die men op Java veelal ziet. De eerste behoeft eerst na 5 tot 10 jaren weer vernieuwing. $\mathrm{Zij}$ is echter even licht ontvlambaar als de atap op Java. Daarom gebruiken hoofden en rijken meestal zinken daken; de in de laatste jaren ten gevolge van de duurte van het zink meer en meer in zwang komende houten dakbedekking (sirap) treft men hier nog weinig aan. Pannen daken ziet men bijna nergens in de geheele Minahassa, om de doodeenvoudige reden, dat er in het geheele land geen pannenbakkerijen bestaan. Onder het volk vindt men nog veel minder ambachtslieden dan onder de Javanen. Timmerlieden echter, die een huis kunnen helpen bouwen, heeft men in elke negorij; trouwens dan kan men zeggen, dat elke huiseigenaar eigenlijk timmerman is. Gewoonlijk geschiedt de huizenbouw met onderling hulpbetoon. Alleen voor het halen van het hout, het behakken en het schaven daarvan en het leggen van de dakbedekking worden vaak menschen gehuurd, wien men behalve loon in geld ook eten dient te geven. Bij het opzetten van het huis wordt de hulp van familieleden en goede kennissen ingeroepen, wien men 
slechts te eten heeft te geven. Bij het bouwen speelt het bijgeloof een groote rol. Men moet bij het leggen van balken en het meten steeds het in aanbouw zijnde huis links laten liggen (makakan $\mathrm{Tt}$., Tb. van $\mathrm{kan}=$ rechts, rechterhand); zoo moesten ook vroeger de Tontèmboansche tuinpriesters en vogelhoorders, als zij om den dorpssteen liepen dien ook links laten. Wanneer een huis eene nieuwe dakbedekking moet hebben, acht men zich hier en daar, o.a. in Tomohon, verplicht een tijgerkleurigen hond (asoe korotéj $\mathrm{Tb}$.) te slachten en op te eten. Ter vervanging van het oude bouwoffer, een menschenschedel, die aan het huis de kracht moest geven om overeind te blijven, legt men thans onder elken paal de een of andere munt. De balken en stijlen moeten goed in elkander passen, anders zou er het geluk van het huisgezin voortdurend door twisten verstoord worden. Heeft men op een stuk grond, waarop het huis gebouwd zal worden, een zwarte slang of duizendpoot gezien, dan gaat de bouw niet door; het opgezette huis zou anders afbranden. Is op een plek eenmaal een huis verbrand, dan bouwt men daar er liever geen meer. Onder de Tontèmboan bestond de gewoonte om voor het zetten van de palen menschen te huren uit een andere negorij. Schwarz (Tontemboansche Teksten, blz. 189) verklaart dit uit het feit, dat tot heden toe nog de vrees bestaat om op zekere gronden te bouwen. Daartoe behooren o. a. de pinala 'oesan in bara' "de plaats waar men eerst aanging als men pas terugkwam van het luisteren naar vogelkreten; men mocht dan n.l. niet terstond naar zijn huis gaan maar moest zich op eene bepaalde plek, meestal bij den ingang van het dorp, nederzetten om pinang te kauwen, even voor de leus te slapen, of wat dan ook te doen, eer men zijn huis binnenging, en de pinala'oesan in dokos, de plaats waar men eerst aanging, als men van een sneltocht terugkwam. "Besloot men later toch op zulke plaatsen te bouwen, dan zette men er eerst een voorloopig huis, doch liet het vervallen en eerst daarna dorst men er een huis te zetten en het te bewonen, omdat nu de grond al eens bebouwd was geweest.»

Wil men het hout gaan hakken in het bosch, dan moeten de hakkers voordat zij de bijl in den boom slaan eerst eens flink kuchen om de geesten te verdrijven. Verder hebben zij te zorgen, dat de eerste boom, dien zij omkappen onmiddellijk rechtuit op den grond valt. Blijft de boom ergens aan hangen, dan wordt 
dit als een kwaad voorteeken beschouwd; die boom wordt niet meer gebruikt en men kan dien dag niet meer met materiaal verzamelen doorgaan.

Ook bestaat het gebruik, dat degene, die een huis voor het eerst betrekt, niet het eerste vuur op de stookplaats mag aanmaken; meestal geschiedt dit door een der oudsten der negorij. Evenmin mag de nieuwe bewoner voor het eerst de lampen aansteken (s o e molo). Dit geschiedt op eenigszins plechtige wijze, ook weer door een der oudsten uit de negorij; op dien zelfden avond wordt dan nog wel hier en daar ma ra mba (Mal.) uitgevoerd, d.i. een inheemsche dans waarbij men in een kring achter elkander staat en een ieder de handen legt op de schouders van den voor hem staanden man of vrouw. Onder het zingen van inheemsche liederen en het rythmische stampen op den vloer, loopt men in het rond. ${ }^{1}$ )

Nog dient vermeld te worden, dat, wanneer het geraamte van het dak gereed gekomen is, het werkvolk onthaald wordt op een welvoorzienen maaltijd (naik goenting, Mal.). Is het dak geheel gereed gekomen, dan wordt de Nederlandsche vlag uitgestoken en geeft men een feestje dat "toetoep katoe» (Mal.) heet.

De gulden tijd, dat nog een ieder het benoodigde hout voor de woning uit nabijgelegen bosschen kon halen, is voor verscheidene dorpen reeds lang voorbij. Daar kapt men dan boomen van de z.g. djoerame- (Mal.) gronden (half verwilderde gronden), van de erven en akkers. Voor balken zoowel als planken gebruikt men bij voorkeur tjempaka oetan (Mal.), of wasian (Michelia Celebia n. spec.) "de kostbaarste en meest gezochte van alle timmerhoutsoorten van de Minahassa»; marintek of kojawoe (Bischofia Javanica Bl.), maoembi (Artocarpus dasyphylla Miq.), het echte toembawa-hout of toembawa-rendai (Td.), toembawa rintek (Tt.) (Dysoxylum densiflorum Mic.), de nantoe (Palaqium obtusifolium Burck) de tongke (Tt.) of kajoe ting (Mal.), een boom die tot de Rizophoren behoort. ${ }^{2}$ )

De kosten van het opzetten van eene woning bedragen on-

1) Zie voor offers vroeger bij het bouwen van eene woning gebracht Wilken IV blz. 57 en de in noot 53 van die bladzijde vermelde litteratuur en blz. 60; voor oude gewoonten betreffende huizenbouw en inwijding $\mathrm{N}$. Pb. Wilken in Mededeelingen van wege het Nederlandsche Zendelinggenootschap 7• jaargang blz. 138 e. v.

2) Zie verder dr. S. H. Koorders. Verslag eener botanische dienstreis door de Minahassa blz. 111. e. v. 
geveer $f$ 150.- $f 600$. , van eene woning van bamboe en niboeng opgetrokken slechts $f 20 .-f 30$.

Gewoonlijk zijn de huizen het bezit van den bewoner, huren van woningen vindt voornamelijk plaats door Inlandsche ambtenaren en beambten, die geplaatst worden in streken waar zij vreemdeling zijn. Overigens is woninghuur onder de bevolking totaal onbekend, van huurwaarde der woning, die belast wordt; heeft zij feitelijk dus geen begrip.

Was de keuken, de haard, vroeger in de woning, thans staat zij" er meestal buiten, vlak achter het huis, en bijna altijd op den grond en omgeven door eene eenvoudige omwanding van bamboevlechtwerk. Fornuizen bezitten nog maar weinigen; men kookt eenvoudig op een kookgat van een uit steenen gefabriceerde kookplaats (amporan, Tt.; ramporan $\mathrm{Tb}$., raramporan Ts.). Voor het gewone keukengereedschap maakte men reeds vanouds gebruik van Rembokkansch aardewerk. Veel was er niet noodig, alleen wat potten en pannen; voor het overige gebruikte men bamboekokers. Die zijn overal voor geschikt, om water te bewaren, vooral de boeloeh djawa (Mal.), de grootste bamboesoort van de Minahassa, die men ook gebruikte om rijst in te bewaren, of om water in te halen (a a s o e Tb., Tt.), om palmwijn op te vangen en mee naar huis te nemen (sintjom Tt., aawèjen $\mathrm{Tb}$.); de koker waarin het kostelijke vocht thuis wordt overgegoten heet in het Tb. potoeng. Dan heeft men nog groote kokers waarin men allerlei gerechten bewaart waar de poes of een ander dier niet aan mag komen, de walosong (Tb.) genoemd. ${ }^{1}$ ) Verder vindt men nog in de keuken borden (pining-kon Tb., loto of koesi Tt.) klapperdoppen, in het Moluksch Maleisch tampoeroeng genoemd, lepels messen, bijlen, mandjes, enz. Vroeger bewaarde men ook in de keuken de salangka' ( $\mathrm{Tt}$. ), eene kist waarin men allerlei goederen van waarde opborg en die als een erfstuk nog steeds in eere wordt gehouden onder de Tomboeloe' (vergelijk de Javaansche grobog). Onder de Tontèmboan had men de bekende heilige kist (tèm boan) waarnaar het volk genoemd is ${ }^{2}$ ) en waarin de rijst werd bewaard, die voor de offerfeesten was afgezonderd.

1) Men zie in het Tontemboansch-Nederlandsch woordenboek door J. A. T. Schwarz onder loeloet, pasolo'd, solong, wow ong.

2) Zie Mededeelingen van het Ned. Zendelinggenootschap deel XXII blz. 275 en XLVII blz, 103 noot 5 en blz. 124. 
Doch laten wij nu een kijkje nemen in de woning. Zoo aardig en zoo net als deze er van buiten uit kan zien, zoo vies en vuil is het er dikwijls van binnen. In de voorgalerij van een gewonen landbouwer ziet men stoeltjes en een tafel, op de bordesjes prijken planten in potjes, voor de ramen hangen min of meer nette gordijntjes, het voorerf ziet er dragelijk uit, in de bovenlanden zelfs beplant met bloemen (de Minahasser is over het algemeen netter op zijn erf dan de Javaan; hij plant er ook geen klappers of voedingsgewassen op), kortom het frontaanzicht is vriendelijk en netjes. In de binnengalerij is het ook nog net, doch niet mooi; de wandversiering, als photo's, papieren bloemen, enz. pleiten niet voor het schoonheidsgevoel van de Minahassers. De slaapkamers en achtergalerij zijn gewoonlijk vuil. Het voornaamste meubel in de slaapkamer is de rustbank waarop men slaapt. Niet altijd worden bultzakken gebruikt, de eenvoudige man slaapt op een mat ( $\mathrm{té}$ pé, Tb., Tt.) gemaakt van riet, goroeroe (Mal.) (bladscheede van den pinang of niboengpalm) of van het zachte gedeelte van de bamboe (salina'). De bultzak en kussens zien er minder frisch uit; een gordijn om het bed kent de kleine man niet, of hij gebruikt eenvoudig matten of wokabladeren als zoodanig. Komt men onverwachts het achterhuis binnen, dan kan het ook daar onzindelijk en vuil uitzien. Er staat daar een tafel en wat stoeltjes, bij de armsten zelfs alleen een tafelvlak van bamboevlechtwerk op vier bamboepooten. De meesten eten gewoon met hun handen uit een bord; lepels en vorken worden alleen gebruikt bij feestelijke gelegenheden en hebben reeds algemeen ingang gevonden onder de districtshoofden en intellectueelen. Is men op den akker, ver van de negorij (men blijft daar dikwijls zeer lang, soms weken, ja maanden) dan is het pisangblad of eenig ander blad het bord. Des avonds ziet men weinig licht in huis branden. De oorspronkelijke Minahassische lamp was de solo (Tb., Tt.), een fakkel gemaakt van een bamboekoker waarin de eene of andere brandstof. Nog eenvoudiger was de verlichting door middel van fijne bamboetakjes, die men in bosjes tegelijk aanstak. Lucifers (in het Maleisch "matjes») waren toen natuurlijk onbekend. Hoe men vuur maakte, beschrijft Schwarz in de Tontemboansche Teksten (blz. 272-273). De toestellen die gebruikt werden heetten in het Tt., Ts. en Td. kakarisoan en kakapojaan (Tt. de Minahassische swastika). Nog vaak moet men in den tuin tot zulke primitieve middelen zijn toevlucht nemen. 
De klapperolie was vroeger als brandmateriaal vrij duur, zij moest toen ingevoerd worden uit de Sangi-eilanden, terwijl zij thans overal overvloedig in de Minahassa te krijgen is. De petroleum bracht natuurlijk een grooten ommekeer, de handelaren in petroleumlampen hadden een goeden tijd! De gasoline is nog maar een vier, vijf jaren hier bekend, gasoline-verlichting ziet men dan ook maar weinig.

Bijgebouwen heeft eene gewone Minahassische woning niet. Eene bepaalde plaats waar men zijn gevoeg pleegt te doen, kent de gewone negorijman niet. Alleen bij negorijhoofden en meer ontwikkelden ziet men achter in den tuin een "roemah ketjil" of "roemah blakang" (Mal.). Badkamers ontbreken gewoonlijk, de meeste negorijen hebben echter afzonderlijke badplaatsen buiten de negorij; vaak baadt men ook buiten in de open lucht in waterleidingen of rivieren. Putten worden daarom dan ook zelden op de erven gegraven. Het drinkwater halen vrouwen en kinderen 's ochtends en tegen het vallen van den avond in bamboekokers van de negorijbron. Verder ziet men op het erf varkenshokken die met moeite door het Bestuur zijn ingevoerd (de varkens liepen vroeger overal rond). Het kippenhok (la langdanga n Tb., lalandangan Tt.), is meestal niet anders dan een lange kooi van bamboe, die achter aan het huis wordt bevestigd.

Rijstschuren treft men op het woonerf niet aan. De landbouwvoortbrengselen laat men vaak achter in de tuinhut (saboea, Mal., popo Tb., Td., loilong, loindong of lawi Tt.), die bijna ieder op zijne ver van het dorp gelegen akkers uit primitieve bouwmaterialen optrekt. Tehuis bergt men den oogst op in een kamertje of op den zolder of vliering (soldor, Mal., patas Tt., Td., solimai, Tt.). Is deze vliering boven de kookplaats aangebracht, dan wordt daar de geoogste maïs gelegd om meteen door te rooken, zoodat zij langer goed blijft.

Het hoofdvoedsel van den Minahasser is rijst (k a n Tb., to e't o e' Tt.). Niet altijd is dit zoo geweest. De verhalen vertellen nog van een tijd, dat men allerlei boom- of plantwortelen, sagowormen (Tontemboansche Teksten. Vertaling blz. 3), vruchten, o.a. van den arenboom, en van een soort liaan (zie dezelfde Teksten blz. 244) enz. nuttigde. Hoe volgens de legende de rijst uit den Hemel (Karondoran) door Toemileng is gestolen, raadplege men de in het $\mathrm{Tb}$. en $\mathrm{Tt}$. uitgegeven verhalen hieromtrent. ${ }^{1}$ )

1) In de eerste plaats raadplege men dan Tont. Teksten Vertaling blz. 244-246, daarna leze men van deze Teksten verhaal $n^{\circ} 100$ en de op blz. 244 vermelde lectuur. 
Men onderscheidt de echte rijst (k a n kare n ga $\mathrm{n} \cdot \mathrm{Tb} .=$ echte rijst of kan.wene' Tb, to e'toe' wene' Tt.; wene' $=$ padi) en de maïsrijst (nasi miloe Mal., kan tondei Tb., toe'toe' tandei Tt.). De laatste wordt in kleine, vroeger ingevoerde Amerikaansche molentjes, die blijkbaar zeer veel ingang hebben gevonden, gemalen. Degenen, die zich geen molen kunnen aanschaffen, stampen de maïs in een stampblok. De nasi miloe wordt gekookt met water (1 kati fijngestampte miloe op-1 Liter water, volgens deskundigen).

Rijst wordt gewoonlijk op de volgende wijze bereid. De gepelde rijst wordt in een pot met kokend water gestort, de pot blijft op het vuur staan totdat het water in de rijst gedrongen is, daarop wordt $\mathrm{zij}$ van het vuur genomen, er naastgezet en telkens omgedraaid om de rijst heet te houden en gaar te laten worden. Vroeger werd de rijst in den koker van een jonge bamboe gekookt. Men hield dien koker, al draaiende en steunende op een plankje, schuin boven het vuur. Ook kookte men de rijst wel in een blad. Men deed de ontbolsterde rijst in bladeren gewikkeld in een pot met kokend water. Hiervoor gebruikte men de bladeren van de la'ikit of laitjitj (Heliconia Bihai L.) en van de globa (Amomum anthoidioides). Deze wijze om rijst te bereiden heet nieloes (Tt., Tb., Td.). Onnoodig te zeggen dat van de rijst meerdere gerechten gemaakt kunnen worden, zooals rijstepap, al of niet met klappermelk, of rijst gepakt in peperhuisjes gemaakt van het blad van den arenpalm, of de bekende nasi djaha gemaakt van kleefrijst (nasi poeloet Mal., k ěta n Jav.) vermengd met klappermelk en wat zout, gepakt in pisangbladeren; is die rijst gevuld met vleesch- of vischgerecht, dan heeft men de bekende la lampa (Mal.) of lemper (Jav.).

Van de maïs makkt men ook allerlei lekkernijen. Jonge miloe fijngestampt, in een maïsblad gewikkeld, wordt gekookt in een bamboe of in een pot; verder wordt zij ook wel gepoft gegeten. Zelfs is van de maïs eene smakelijke pudding te maken, de z.g. kokole en ook eene niet te versmaden soep, gekookt van fijngesneden maïs, gemengd met specerijen of groenten, of fijngesneden visch of vleesch.

Het Minahassische eten is over het algemeen zeer vet. Het is haast onbegrijpelijk, dat een volk zulk een zwaar eten in dit tropisch klimaat kan verdragen. Wat het maal zoo vet maakt zijn de van varkensvleesch bereide gerechten. Spek; hetzij al of 
niet gerookt of in het zuur gezet ( $\mathrm{ta} \mathrm{w}^{\prime}$ ) is bijv. een gelief koosd eten. Eigenaardig is het, dat vele vleeschgerechten in bamboekokers worden bereid of bewaard; de bamboe geeft blijkbaar aan het eten een bijzonder aangenamen smaak. Zoo wordt fijngestampt vleesch met beentjes en kruiden maandenlang in een drogen bamboekoker goedgehouden.

Het varkensvleesch is niet de eenige vleeschsoort, die hier gegeten wordt. Hondenvleesch, vleermuizen-, in Tonsawang zelfs slangenvleesch wordt niet versmaad. Eene lekkernij zijn ook de geroosterde muizen; zij worden boven het vuur gehouden, totdat de haren bijna geheel verschroeid zijn, daarna worden de ingewanden eruit gehaald en kan het vleesch gegeten worden. Rundvleesch wordt weinig gebruikt. Vischgerechten daarentegen kent men over de geheele Minahassa.

Groentenspijzen worden in velerlei variatie's bereid. De meest bekende daarvan is de tinoetoe'an (Tt.), een ratjetoe van allerlei'groenten met kruiden. Verder is ook een zeer geliefde spijs de ped'al of pela'ar, eene groentesoep, vermengd met gestampte rijst of maïs, die naar men zegt den eetlust opwekt, ofschoon het den Minahasser daaraan niet ontbreekt. Het is opmerkelijk welk een groote hoeveelheden eten naar binnen worden gewerkt. Als voorschotel eet men ook wel verschillende groenten met kruiden, doch zonder zout. De bladeren van de jonge maïs moeten ook lekker smaken, vooral gemengd met sago. Groenten die in den bamboekoker worden bereid zijn ook bekend. Worden zij met vleesch zonder water gekookt, dan heet dat in het $\mathrm{Tt}$. winongos.

Men eet thans driemaal per dag, s'ochtends (soemokol Mal. $=$ smokkelen), midden op den dag en 's avonds om 7-9' uur. Het hoofdmaal is midden op den dag, dan eet men rijst of maïs met de bijgerechten. Vaak eet men dan nog wat toe; gewoonlijk gepofte aardvruchten, pisang of jonge maïs. Zelden wordt sago geheeten, alleen wanneer er werkelijke voedselschaarschte heerscht, gaat men er toe over sago te kloppen; voor de bewoners van Tonsawang is het echter hoofdvoedsel.

$\mathrm{Op}$ feesten en wanneer men Europeanen te gast heeft krijgt men een uniform menu af te werken, dat weer eene nabootsing is van de Europeesche tafel: soep, pastei, dan rijsttafel, sla en ten slotte werkelijk heerlijke gebakken, taarten die de Minahassische vrouw voortreffelijk toebereidt. Bij. feestelijke gelegen- 
heden begint men dan wel eens na zoo'n ellenlang maal eerst met het echte Minahassische eten.

De volksdrank bij uitnemendheid is de palmwijn, sagoweer (Mal.) péhé of timpa (Tl.) el epen (Tb.) pe' of oepe' (Tt.). Men verkrijgt het vocht door eene insnijding in den mannelijken bloemkolf van den arènpalm (seho Mal., a'k ěl Tb., Td., Ts.) die te voorschijn komt als de boom drie à vier trossen (h o ea h batoe, Mal.) gekregen heeft. Is de majang (Mal.) (bloemkolf) al eenige dagen lang geregeld beklopt en al zacht genoeg geworden, dan vangt men het vocht op in een bamboe van twee geledingen. Als het pas is getapt is het vocht zoet; de Minahasser gebruikt het liever wat verzuurd door gisting ${ }^{1}$ ). Zoo ziet men des avonds en des ochtends den landman met zijn gevulden koker aan een touw over den schouder huiswaarts keeren. De sagoweer immers kan slechts één dag bewaard worden, mits in een flesch. In de kotta Menado (waar de sagoweerverkoop verpacht is) wordt de drank vermengd met de bittere schors van de Kira-kira (Mal.) (Capapa) waardoor zij een dag langer bewaard kan worden.

Vroeger had iedere Minahasser bij den palmboom eene drinkplaats, de pengelepan, waar gewoonlijk vrienden samenkwamen om te drinken en te praten. Nu ziet men langs de wegen overal verkoopplaatsen, waar men het kostelijk vocht tegen 5 cents per Apolinaris-flesch verkoopt; is het verkeer druk, dan stijgt de prijs natuurlijk.

Men kan niet zeggen, dat drankmisbruik niet voorkomt. Er wordt veel en vooral regelmatig gedronken, ook onder de vrouwen. Als deze het als jonge meisjes niet gewoon waren, gaan zij het doen wanneer zij moeder zijn, omdat zij met palmwijn meenen het zog op te wekken. Het overmatig gebruik van sagoweer, dat aan de beloopen oogen van den drankzuchtige te zien is, heeft voornamelijk tengevolge, dat men podagra (soepi' Tt.) krijgt.

\section{Huwelijk.}

Het verkeer tusschen jongens en meisjes kan in de Minahassa vrij genoemd worden. Er zijn gelegenheden te over voor den jongen man om het meisje zijner keuze te vinden. Het mapaloes, het onderling hulpbetoon bij de landbouwwerkzaamheden (eene

1) Zie verder Koorders t. a. p. blz. 286-289. 
instelling waarop ik aan het eind van dit hoofdstuk weer terug kom), is wel de gelegenheid waar de meeste liefdesbetrekkingen worden aangeknoopt. Jongens en meisjes gaan dan onder leiding van ouderen in clubjes te zamen naar de meestal ver van het dorp gelegen akkers, en blijven daar een geheelen dag samen werken. De jongen die reeds een meisje op het oog heeft, tracht op allerlei wijzen hare genegenheid te winnen; hij draagt haar patjol, gaat naast haar werken, neemt zooveel mogelijk haar aandeel van het werk over, haalt voor haar jonge klappers en sagoweer, terwijl het meisje van hare zijde door het geven van tabak van hare liefde doet blijken.

Ook op feesten en danspartijen ontmoeten jongens en meisjes elkander. Echte volksfeesten kent de Minahasser niet meer. Met den overgang tot het Christendom zijn zij natuurlijk verdwenen of door andere gelijksoortige vervangen. ${ }^{1}$ ) Van de van de Europeanen overgenomen feesten kan men noemen het vieren van den Oudejaarsavond en van den Nieuwjaarsdag, zelfs ook van den eersten Zondag na laatstgenoemden dag (koentji tahoen baroe Mal.) Op die dagen gaat een ieder mooi uitgedost naar de kerk, na afloop waarvan men elkander bezoeken gaat brengen; er wordt gegeten en gedronken, terwijl de dag met danspartijen besloten wordt. De Christelijke feestdagen worden niet op bijzondere wijze gevierd. Een algemeen gebruik is het wel op Kerstnachten (en ook op Oudejaarsavond) vele lichten aan te steken, vooral in de voorgalerij ("voorhuis», zooals de Minahasser zegt) en op de kerkhoven. Deze gewoonte is vooral in het district Tompasso (in het $Z$. W. van de Minahassa) sterk in zwang. - Van de heidensche feesten die nog hier en daar voorkomen, vallen nog te vermelden: het inwijden van een nieuw huis waarbij de uitgenoodigden in een kring achter elkaar staan en ieder de handen legt op de schouders van zijn voorman, waarop men al stampende onder het zingen van oude volksliederen rondgaat. Deze dans heet $\mathrm{maramba}$; dikwijls gaat daaraan vooraf het aansteken van lampen in het nieuwe huis, die een geheelen nacht door moeten branden. - Dan bestaat er ook nog het oogstfeest, waarbij vroeger een dans, het z.g.

1) Voor beschrijving van heidensche feesten zie men Graafland blz. 285 e.v. en N. Th. Wilken. Bijdragen tot de zeden en gewoonten der Alfoeren in de Minahassa. (Mededeelingen van het Nederl. Zendelinggenootschap 7• jaargang blz. 295 e. v.).

Dl. 81 . 
$\mathrm{m}$ a è $\mathrm{ng} \mathrm{kèt} \mathrm{t}$, werd uitgevoerd, die thans, naar wij meenen, geheel verdwenen is of misschien nog sporadisch in enkele heidensche streken voorkomt. ${ }^{1}$ ) Het zingen van oogstliederen behoort gelukkig nog niet tot het verleden (in het Tontèmboansch heet het maowei) doch algemeener is thans Europeesche muziek, meestal bestaande uit fluit en trom, die gedurende het oogsten wanneer een geheele mapaloesgroep bezig is, worden bespeeld; na den oogst wordt op het veld in een hutje (saboeah Mal.) gegeten. $\mathrm{Na}$ den oogst wordt in sawahstreken in de kerk een dankdienst gehouden (pengoetjapan sjoekoer Mal.); ook bestaan oogstfeesten door verschillende naburige Christengemeenten tezamen in de open lucht gevierd (vooral in Tondano).

De verjaardagen van het Koninklijk huis zijn eveneens dikwijls aanleiding tot feestvieren; een bijzonder volkskarakter heeft die feestviering uit den aard der zaak niet.

Het belangrijkste punt op de Minahassische feestprogramma's zijn de danspartijen, de dansi-dansi's, waarop de gewone Europeesche wals, kruispolka, lanciers quadrille, enz. worden gedanst; met bewonderenswaardige behendigheid wordt op allerlei schoeisel en in allerlei vreemde kleedij, op oneffen houten, leemen dansvloeren rondgesprongen; de Minahasser is eenvoudig verzot op dansen. Inheemsche dansen bestaan bijna niet meer; mogelijk is het menari zooals men dat op vele cdansi-dansi's» ziet, een oorspronkelijke Minahassische dans, doch wij betwijfelen het zeer.

Men ziet het: aan gelegenheden waar jongens en meisjes elkaar kunnen ontmoeten ontbreekt het zeker niet.

Heeft de jongeling zijne keuze gedaan, dan stuurt hij een kennis naar het jonge meisje om eens te polsen of zij hem eveneens genegen is. Deze tusschenpersoon noemt men in het Tomboeloe'sch en in het Tontèmboansch gaga ren, in het Bantiksch aingka ${ }^{2}$ ); meestal is het eene vriendin of een familielid van het te vragen meisje; soms weet zoo'n slimme postillon d'amour het zoo aan te leggen, dat zij zelf de uitverkorene wordt. Meer moderne jonge menschen doen hunne liefdesverklaring per brief.

1) Zie Internationales Archiv für Ethnographie 1905 en J. A. T. Schwarz. Tontemboansche Teksten. Vertaling blz. 257 e. v. Bij de Tontemboan heette het oogstfeest manempo'.

2) Zie P. A. Mandagie. Nota betreffende Bantiksche aangelegenleden in het Tijdschrift Binuenlandsch Bestuur deel 48 (1915) blz. 28 en 49. 
Is het antwoord van het meisje gunstig, dan worden de ouders van den jongen pas ingelicht. Over het algemeen dus wordt op de keuze weinig dwang van de zijde der ouders uitgeoefend. Niet overal schijnt men ten deze echter even liberaal te zijn; in Tonsea is dikwijls te groote invloed van de zijde der ouders op de huwelijkskeuze hunner kinderen oorzaak van eene spoedige echtscheiding. Typisch is de gewoonte bij de Bantikkers om rechtstreeks het huwelijksaanzoek bij de ouders van het meisje te doen, uit vrees dat de jongeman geen toestemming tot het huwelijk van zijne eigen ouders zal krijgen (matingkaran) ${ }^{\mathbf{1}}$ ).

$\mathrm{Nu}$ moeten de ouders van den jongen op hun beurt de ouders van het meisje omtrent het voornemen van hun kind in kennis stellen. Daartoe maakte men en maakt men nog gebruik van de alom in de volkskunde van de geheele wereld bekende huwelijksmakelaars. Het woord duidt reeds aan wat de taak dier personen is: niet alleen het overbrengen van een huwelijksaanzoek, doch tevens het inleiden van de onderhandelingen omtrent den bruidsschat. Men noemt deze tusschenpersonen waloek (Tb.), w a d o e k (Ts.), rèr è o' a n (Td.), p a b o e s e i a n (Langoan). Daartoe worden meestal bejaarde bloedverwanten uitgekozen, die doorkneed zijn in de plaatselijke regelen omtrent den bruidsschat; met groote omzichtigheid en de noodige breedsprakigheid voeren zij de onderhandelingen. Bij de Bantikkers werden (en worden soms nog) twee personen daarvoor uitgekozen, gewoonlijk oude vrouwen, die noch familie van den jongen man, noch familie van het meisje mochten zijn (rarampang) ${ }^{2}$ ). Nog bestaat hier en daar de door Mr. J. H. Carpentier Alting ${ }^{3}$ ) vermelde gewoonte, dat bij het eerste bezoek (niet altijd kunnen de onderhandelingen in één bezoek afgedaan worden) de huwelijksmakelaar(ster) wat wit of zwart katoen medeneemt "om den mond te openen" (oem boeka oen soema Tb., Ts.), een geschenk dus aan de ouders van het meisje met de bedoeling hen aan het praten te krijgen; een extra geschenk moet soms nog medegenomen worden wanneer de beide jongelieden in nauwe familiebetrekkingen tot elkander staan. Dit geschenk dient, zooals de Minahassers

1) Zie P. A. Mandagie t.a.p. blz. 49.

2) Zie Mandagie t. a. p. blz. 49.

3) Zie Mr. J. H. Carpentier Alting. Regelingen van het privaatrecht voor de Inlandsche bevolking der Minahassa-districten van de residentie Menado 1e gedeelte 1e stuk blz. 50 . 
dat in beeldspraak zeggen, "om iets door te snijden» (pontol Tb.) of om "de grenzen te overschrijden" (lo e mèwo'in tawa'ang Tt.) ${ }^{1}$ ).

In Ratahan en Tonsawang zijn huwelijksmakelaars onbekend. In Ratahan werd vroeger het huwelijksaanzoek gedaan door de moeder van den jongen aan de moeder van het meisje. Men noemde dit wisaha 'mbawinei d.i. de beraadslaging der vrouwen ${ }^{2}$ ), terwijl de handeling van het aanzoek zelf heet: makina $=$ een verzoek doen. Al meer en meer gaat dit gebruik verdwijnen om vervangen te worden door eene briefwisseling tusschen de jongelieden. Op die wijze geschiedt thans ook al het huwelijksaanzoek in Tonsawang, tenminste, indien de ouders geen bijzonderen invloed op de trouwplannen van hun zoon willen uitoefenen, anders gaan zij zelf om de hand van het meisje vragen. Vroeger hadden de heidensche priesters, de walian's, die taak te vervullen. Vooraf werd den jongen man door zijne ouders gelast zich naar de woning van het meisje te begeven om haar te vragen in dat huis te mogen slapen. Dit heette mangila' boan $=$ een slaapplaats zoeken. Stond het meisje het verzoek toe, dan beteekende dat een aannemen van het aanzoek en bleef haar verloofde twee, drie nachten in de voorgalerij van het huis slapen. Daarop volgde het huwelijksaanzoek der walians; het toestemmend antwoord der andere partij bestaat dan voornamelijk in het aanbieden van pinang en sirih ${ }^{3}$ ).

Op het huwelijksaanzoek volgt de officieele verloving, meestal in eene bijeenkomst ten huize van de ouders van het meisje. Vroeger werden op deze bijeenkomsten de beide jongelieden niet toegelaten, doch met het meer en meer veldwinnend individualisme en de daarmee gepaard gaande vrije huwelijkskeuze gaat men met deze ongelukkige gewoonte breken. Bovendien worden in den laatsten tijd deze bijeenkomsten alleen beperkt tot de beide ouderparen en slechts enkele naaste familieleden; het huwelijk wordt in streken met de meest vooruitstrevende

1) De tawa'ang is een plant, die meestal als grensteeken wordt gebruikt. Loemèwo in tawa'ang beteekent feitelijk: ${ }_{n}$ (de boete wordt betaald voor) het schenden der grenzen".

2) Onjuist is de vertaling van Mr. J. H. Carpentier Alting t.a. p. bly. 50: nom alles uit te maken".

s) Vandaar het woord mata'aningangan. Zie Carpentier Alting t. a. p. blz. 57 . 
bevolking geleidelijk van eene familiezaak meer een zaak van beide betrokken partijen en de wederzijdsche ouders. Eerst op deze bijeenkomst komt de verloving tot stand. In de Tontèmboansche landen, meer in het bijzonder Sonder en Kawangkd'an, heet die bijeenkomst dan ook po'ow in doma, (in het Maleisch over bijna de geheele Minahassa poetoes soewara) hetgeen beteekent de beslissing omtrent de trouwbelofte of de verloving.

Alleen in Bantik komt de verloving op eene andere wijze tot stand. Op den dag der verloving, die hier doe mapo heet, gaan de huwelijksmakelaars, de z. g. niabi'ang, een gedeelte van den bruidsschat naar de woning van de bruid brengen. De familieleden van beide verloofden komen niet samen, doch vereenigen zich ieder afzonderlijk in de woning van den jongen man en van het jonge meisje. ${ }^{1}$ ) Het overhandigen van het genoemd geschenk voorheen wellicht een middel om de door de verloving ontstane magische kracht te weren, is thans meer eene symbolische uiting van de trouwbelofte. - $\mathrm{Bij}$ de overige stammen vindt men een dergelijk teeken van de trouwbelofte niet; tenzij men het straks te bespreken «antar pakeian, ${ }^{2}$ ) als zoodanig wil beschouwen. Overigens bemerkt de buitenwereld al spoedig, dat de verloving tot stand is gekomen. Een ieder ziet nu den jongen man bij zijne aanstaande schoonouders werken; reeds voor de verloving heeft hij door zijn ijver te toonen de genegenheid van de ouders zijner beminde trachten te winnen, maar gedurende de verloving mag zijne energie niet verslappen. Ook noemen de verloofden elkander niet graag meer bij den naam. zelfs als zij later man en vrouw zijn geworden blijven zij verlegen om elkanders naam te noemen. Ook komt hij geregeld zijn meisje bezoeken, liefst 's avonds.

Graafland vermeldt in zijn welbekend boek ${ }^{3}$ ) op grond van door hem aangehaalde Tombariri'sche minneliederen ${ }^{4}$ ), dat de jongeling niet zelden zijne verloofde des nachts in haar slaapvertrek kwam opzoeken; zelfs waren de ouders van het meisje

1) Mandagie t.a.p. blz. 29.

2) Verschillende gebruiken en gewoonten hebben Maleische benamingen, die in de Minahassische talen onbekend zijn, tenzij zij uit het Maleisch zijn vertaald. De Ambonneesche onderwijzers, die de eerste zendelingen hielpen met hun bekeeringswerk, hebben die woorden ingevoerd (masoek minta, poetoes soewara, antar pakeian, bakoe piara, enz.)

s) Graafland 1 blz. 465.

4) Idem deel 1 blz. 161 en 162. 
trotsch op dergelijke bezoeken. Wellicht hebben wij hier te doen met de nachtelijke vrijages in eer en deugd, zooals die in Duitschland bestonden en op Texel en Vlieland nu nog onder den naam van kweesten, en in den Indischen Archipel ook voorkomen of althans voorkwamen (o.a. onder Bataks en Dajaks) ${ }^{1}$ ), doch aangezien reeds Graafland mededeelt, dat aan de eer en deugd nog wel een en ander ontbrak, was het wellicht oudtijds reeds geoorloofd gedurende de verloving geslachtsgemeenschap uit te oefenen, eene zede, die bij verschillende volkeren is aangetroffen ${ }^{2}$ ). Hoewel na het ingevoerde Christendom de publieke opinie ten deze zich wel eenigszins gewijzigd heeft, schijnen nachtelijke, heimelijke samenkomsten nog vrij veel voor te komen vooral ook wanneer van de zijde der ouders de "stille verkeering» hunner kinderen wordt tegengewerkt. Verscheidene penoeloeng's (Inlandsche godsdienstleeraars) zelfs wisten mij daarvan te vertellen. De publieke opinie keurt ze niet af, men ziet zoo iets door de vingers, mits de verloving reeds officieel bezegeld is. Echter bezwangert de jonge man zijne verloofde ook wel, om zijne aanstaande schoonouders voor een feit te stellen, zoodat zij hunne dochter dan maar afstaan, om haar uit de moeilijkheid te redden.

In dit verband zij een enkel woord gezegd van concubinaat en prostitutie. Hoewel reeds van ouds monogamie de eenige bekende huwelijksvorm was, was concubinaat geoorloofd; doch alleen de hoofden en vermogenden waren in staat er bijzitten op na te houden; die bijzitten waren tevens werkkrachten. Onder invloed van het Christendom is het concubinaat sterk verminderd en wordt het vooral wanneer hoofden zich daaraan schuldig maken, laakbaar geacht; in allen gevalle komt het opnemen van eene bijzit in de echtelijke woning niet, of althans zeer zelden voor. Prostitutie als beroep komt, behalve op de kustplaatsen, niet voor en is ook nooit in de Minahassa bekend geweest. Men zou daaruit de conclusie moeten trekken, dat vrije liefde voor het huwelijk - hoewel laakbaar - toch wel moet voorkomen ${ }^{3}$ ), doch het is gewaagd hierover eene besliste meening

1) Zie G. A. Wilken. Verspreide geschriften verzameld door Mr. F. D. E. van Ossenbruggen deel I blz. 511-513.

2) Onderzoek naar de maagdelijkheid van de jonggehuwde is naar ik meen geen algemeene gewoonte, al eischen sommige ouders dat.

$\left.{ }^{3}\right)$ De groote ethnoloog H. Schurtz zegt in zijne ${ }_{n}$ Altersklassen und Männer- 
uit te spreken. Onder de landbouwende bevolking van de bovenlanden zijn de zeden echter aanmerkelijk beter dan onder de bewoners van de kustplaatsen, vooral te Menado. Een teveel aan vrouwen, dat wel is waar nog niet met deugdelijk cijfermateriaal is aangetoond, doch op goede gronden verondersteld kan worden, werkt eene toeneming van de onzedelijkheid in de hand.

Op de bovenbedoelde familiebijeenkomsten wordt ook de bruidsschat besproken; zijn er vele personen bijeen, dan bieden en loven de woordvoerders van beide zijden - vroeger onder het kauwen van pinang, thans meer onder het drinken van thee totdat men het eens is over de geldsom of de hoeveelheid goederen welke aan de bruidsouders gegeven zullen worden. Deze bijeenkomst heet dan ook wel pèko (Ts.), dat het kombuigen der vingers bij het tellen, beteekent ${ }^{1}$ ).

In 1902 voorspelde $\mathrm{Mr}$. J. H. Carpentier Alting ${ }^{2}$ ) dat de bruidsschat spoedig zou verdwijnen. Die voorspelling is nu, zeventien jaar later, niet uitgekomen.

In den vorm van den bruidsschat is echter eene groote verandering gekomen. Vroeger noemde men dien in verschillende talen roko' (Tb., Ts., Td.) of hoko (Bt.) of hokop (Rt.) hetgeen lijnwaad beteekent ${ }^{3}$ ); men betaalde dus vroeger in lijnwaden (ook wel in borden). Nu komt die wijze van betalen maar zelden meer voor, alleen de heidensche bevolking houdt zich nog aan die gewoonte. Zoo werd dan nog tot voor kort onder de heidenen van Ratahan de hokof betaald met elf (een blijkbaar door het dorpsbestuur bepaald getal) blokken wit goed. In de laatste oorlogsjaren heeft men die gift van wege de dure prijzen van lijnwaden veranderd in elf rijksdaalders. Meer en

bünde" blz. 190: „In Wahrheit treten käufliche Weiber überall dort sofort auf, wo der ungebunde Geschlechtsverkehr der Jugend unterdrückt wird, ohne dass man durch ausserordentlich frühe Ehen die sonst unvermeidlichen Folgen hintanhalt.

1) In het Tontèmboansch zegt men to emantoe; in Tombariri en Tomohon spreekt men ook wel van noemoewoe'oem pamaja' (over den bruidsschat spreken.)

2) Zie Regeling 1e gedeelte, 1e stuk blz. 69.

3) In het Tt. heette bruidsschat toewar, ook irang, ofschoon men hiermee meer aanduidde giften aan familieleden van de bruid of an de walian's. Thans zijn meer gebruikelijk de woorden antarèn ( $\mathrm{Tb}$. en Td.) iower, afgeleid van het Hollandsche "over" in "overbrengen", of i wè h̀ (Rembokken), wa'er in soesoe of teles i mewangko (Tombaso', waar Tt. gesproken wordt), 
meer wordt ook buiten Ratahan de bruidsschat, de harta kawin, zooals die in het Moluksch Maleisch heet, in geld voldaan. En niet alleen in geld, maar ook in roerende goederen als karren, vee, sieraden, kleederen, in onroerende goederen als grond, boomen, huizen en vijvers. $\mathrm{Er}$ is in de bruidsschatsbetaling nog meer veranderd. Vroeger werd de roko' door de familie van den bruidegom aan de familie van de bruid gegeven; het was dus eene gift van de eene familie aan de andere ${ }^{1}$ ). Ieder familielid van den jongen man was verplicht tot het geven van eene bijdrage (roeroep Tb., roekoep Tt., sambaga tahana Bt.) doch kreeg dan tevens t. z. t. aanspraak op een deel van den bruidsschat voor eene dochter van hetzelfde ouderpaar en op eene gelijke bijdrage, indien een zoon van hemzelf in het huwelijk trad. Thans echter is de bruidsschat meer en meer geworden eene gift van de ouders van den bruidegom aan de ouders van de bruid, of ook wel eene van den bruidegom aan de ouders der bruid of zelfs aan de bruid zelve. Hiermede is natuurlijk niet gezegd, dat hulp van de familie niet meer voorkomt; men treft die zelfs vrij algemeen aan in een groot district als Tonsea', terwijl overal in de Minahassa, speciaal onbemiddelde bruidegoms den steun hunner familieleden in het bijeengaren van de huwelijksgift behoeven, tenzij de bruidjes zich tevreden stellen met een stel bruidskleeren (dikwijls nog voor de trouwgelegenheid gehuurd), eene gewoonte, die, gelukkig, al meer en meer ingang vindt; zelfs deelde de penoeloeng Rawoeng van Tombasian-Atas (Kawangkoan) mij mede, dat er wel huwelijken gesloten waren in zijn ressort zonder dat er eenige bruidsschat aan de bruid was gegeven. Dit feit zou eene verbetering van eene dikwijls verfoeilijke Minahassische maatschappelijke instelling zijn. Vooral in de districten Tonsea' en Maoembi wordt het bedrag van den bruidsschat tot in het oneindige opgedreven; de aanstaande huisvader wordt dan genoodzaakt zich al dadelijk in schulden te steken of bezittingen te verkoopen, een allesbehalve benijdenswaardig huwelijksbegin!

Bij een tweede of verder huwelijk is gewoonlijk de bruidsschat aanmerkelijk minder.

Ook de typische bruidsschatbepalingen der Bantikkers zijn sedert hunnen overgang tot het Christendom vrij snel verdwenen; onder

1) Zie Carpentier Alting 1e stuk blz. 51 en prof. mr. C. van Vollenhoven, Het adatrecht van Nederlandsch-Indië deel I blz. 337. 
de heidenen komen zij nog voor. De bruidsschat bestond uit verschillende giften. De niabi'ang, eigenlijk de prijs voor het bestijgen van de trap der ouders van het meisje, tevens een uiterlijk teeken van trouwbelofte, noemde ik reeds; dit gedeelte van den bruidsschat wordt nog steeds betaald. De eigenlijke kern van den hoko was de z.g. boetoerang en de boengoeroe pitoe. De laatste mocht de moeder (de Bantiksche vader had oudtijds blijkbaar weinig in te brengen) alleen van één harer dochters, mits die nog maagd was, eischen, anders mocht de moeder slechts boeng o e r a $1 \mathrm{im}$ a vragen, hetgeen ruim $\mathrm{f} 50$.minder was. Het woord boetoerang vertaalt Mandagie met «bindsel der beide families», de gift dus, die den symbolischen band vormt tusschen de verwanten van bruid en bruidegom. Bovendien moest nog betaald worden de ta d a (voor het betreden der eerste trede van de trap) en $\mathrm{h}$ a $\mathrm{ng}$ a (voor het richten der eerste vraag aan de moeder van het meisje). In totaal bedroeg zoo'n bruidsschat ongeveer 90 reaal (men rekende en rekent nog steeds volgens het oude muntstelsel) d. i. dus $90 \times$ f $1.56= \pm$ f 140 . Is het meisje eene bloedverwante van den jongeling, dan werd (en wordt nog) evenals bij de andere Minahassische stammen nog boven genoemd bedrag de z.g. pat a t a b a n g gegeven, welk woord doorsnijding beteekent.

Eenig, voorzoover mij bekend, in de Minahassa is de teruggave van een gedeelte (een zesde) van den bruidsschat, de z.g. serangka, d.i. de vergoeding voor eventueele tekortkomingen van de familieleden van het meisje bij het ontvangen der familieleden van den jongeling ter gelegenheid van zijn huwelijk. Onder de Christenen bestaat deze gewoonte niet meer. Men onderscheidt onder hen trouwens geen bepaalde gedeelten meer van den bruidsschat, men spreekt niet meer van boetoerang, hanga of tada (de niabi'ang is zooals gezegd nog steeds in gebruik), de rarampang's bepalen thans in overeenstemming met de ouders der bruid een bepaald bedrag, dat hoko'n sahani (de Christelijke bruidsschat) wordt genoemd ${ }^{1}$ ).

Op een vooraf bepaalden dag moet de bruidsschat zoodra de bruidegom dien bijeen heeft, naar het huis van de bruid gebracht worden; men gaat dan in optocht, een man voorop met een koffer waarin de bruidskleederen en sieraden, geld, enz. naar

\footnotetext{
1) Zie voor deze oude bruidsschatbepalingen Mandagie t.a.p. blz. 49.
} 
de bruidsouders, die met hunne familie den stoet opwachten. Men noemt dit moderne gebruik hantar pakeian ${ }^{1}$ ). Gedurende het overdragen van den inhoud van den koffer wordt vaak de trouwbelofte door bruidegom en bruid uitgesproken.

De bruidsschat in de Minahassa is dikwijls als een koopsom beschouwd. Prof. G. A. Wilken ontkent dat eenigszins en meent, dat deze instelling oorspronkelijk de beteekenis moet hebben gehad van eene zoengave wegens de de vrouw en haren stam aangedane beleediging. Oorspronkelijk moeten n.l. volgens dezen geleerde de vrouwen uit een stam (of menschengroep) geroofd zijn; daarop volgde bloedwraak van den beleedigden stam, die weer later door eene zoengave (den bruidsschat) afgekocht kon worden ${ }^{2}$ ).

Kennen zelfs de Mohammedaansche Minahassers van Ponosakan de instelling van den bruidsschat ${ }^{3}$ ) (bij hen sali genoemd), in het district Tonsawang is zij totaal onbekend. De zendeling Wiersma merkte dit reeds in zijne «Ervaringen gedurende mijn twaalfjarig zendingsleven» (blz. 89) op. ${ }^{4}$ ) Wel moest vroeger een

1) Vandaar het woord antaren voor bruidsschat. In Sonder en Kawangkoan zegt men voor anter pakeian ook wel toemoeroek im pakeian, het overdragen van de kleederen, en in de Tomboeloesche land. $n$ mahali oem p a maja $=$ kleederen brengen.

2) Zie Verspreide geschriften deel 1 blz. 189-192 en 377 .

Tegen deze door Wilken en andere groote ethnologen verkondigde hypothese zijn ernstige bedenkingen geopperd door manuen van naam als van Gennep (Les rites de passage, blz. 175) en P. Sartori (Sitte und Brauch deel 1 blz. 74-75), die niet kunnen aannemen, dat het z.g. roofhuwelijk een algemeene huwelijksvorm is geweest; gewoonlijk toch werden geroofde vrouwen tot bijzitten of slavinnen verklaard, nooit werden zij wettige vrouwen. - Mr. van Ossenbruggen in zijn "Het primitieve denken zooals dit zich uit voornamelijk in pokkengebruiken op Java en elders" (Bijdragen tot de Taal- Land- en Volkenkunde van Ned. Indië deel 71 afl. 1 en 2, blz. 245-246 van den overdruk) is geneigd aan te nemen, dat de bruidsschat oorspronkelijk niet anders is geweest dan eene bezwering van de magie, die men zich als gevolg van een huwelijkssluiting dacht. Dr. Adriani merkt naar aanleiding hiervan op, dat ook naar zijn oordeel de meening van Wilken niet houdbaar is. Immers kwam van ouds ook in de Minahassa de man bij de vrouw inwonen.

In het $\mathrm{Tt}$. was dan ook de benaming van den man, volgens dezen taalgeleerde, nsi mena-na' a si... (volgt de naam der vrouw)" $={ }_{n}$ bij die woont bij...."; en van de vrouw: "si pena-na'an i.... (rolgt de naam van den $\operatorname{man})^{\prime \prime}={ }_{n} z i j$ bij wien wordt ingewoond door....".

3) Zie over betaling van den bruidsschat onder de Mohammedaansche bewoners van de Minahassa, Carpentier Alting 1e stuk blz. 153-154.

4) Onjuist is de mededeeling van Graafland deel $1 \mathrm{blz} .464$. Zie ook Carpentier Alting I 1e stuk blz. 58.- Zelfs onder personen uit Tonsawang afkomstig vindt men er nog, die niet weten, dat de To-en-sini geen bruidssohat kennen. 
weduwnaar, wanneer hij met eene weduwe trouwde aan laatstgenoemde iets (docho werd zoo'n gift genoemd) geven om de schande te bedekken (popon i sokia), of ook wel bēhē oro), omdat wellicht het trouwen met eene weduwe zeer geminacht werd, hetgeen bij vele volkeren nog het geval is en trouwens volgens Controleur de Clercq ook onder andere Minahassische stammen afgekeurd werd ${ }^{1}$ ). Ook bij de Bantikkers heeft vroeger de gewoonte bestaan, om bij een huwelijk met eene weduwe een extra bedrag aan de bruid te betalen; dit noemde men tèngkèsé. Tèngkèsé beteekent n.l. het oplichten van een hoofddeksel, in dit geval de kap, die het gezicht der weduwe gedeeltelijk bedekte. De heidensche Tonsawangers eerbiedigen de oude adat nog wel, bij de Christenen echter krijgt de bruid, alleen meer als geschenk, eerst bij het aanzoek een baadje en sarong, later voor het huwelijk bruidskleederen en eenige sieraden.

Er bestaat in de Minahassa ook eene soort van vrij huwelijk, eveneens onder de Christenen, dat niet op de gewone wettige wijze tot stand komt en waarbij geen bruidsschat wordt betaald. Bakoe piara (elkander onderhouden) heet het in het Minahassisch Maleisch.

Ten onrechte n.m.m. wordt dit bakoe piara als een adatshuwelijk beschouwd; het feitelijk criterium van het oude heidensch huwelijk was toch het geven van den bruidsschat. En nu is juist dikwijls een der oorzaken van bakoe piara het onvermogen, ook de onwil om een bruidsschat bijeen te garen. Een der oorzaken, zeg ik. Het kan ook voorkomen, dat de jongelieden tegen de heden ten dage zoo opgevoerde kosten van toelis nama en huwelijk opzien, of, dat de ouders hunne echtvereeniging tegenwerken; anderen weer hebben minder deugdelijke motieven. Over het geheel genomen, meen ik opgemerkt te hebben, dat in de negorijen waar de kerkeraadsleden weinig zedelijken invloed op de gemeente hebben, het bakoe piara niet door de publieke opinie wordt afgekeurd; de liefdesband kan bij bakoe piara vaak hechter zijn dan in menig wettig huwelijk. Anders is de gewoonte onder de Bantikkers, christenen zoowel als heidenen om wel een bruidsschat te betalen, maar geen volgens de wet voorgeschreven huwelijk aan te gaan; voor dezen bestaat het bezwaar, dat de wettige huwelijksvorm hen

1) Zie Tijdschrift van Nederlandsch-Indië 1870 deel 2, blz. 3 . 
belemmert gemakkelijk den echtelijken band weer te verbreken; echtscheidingen komen onder dat volkje namelijk veel voor.

De Minahassische vrouw heeft in het huwelijk eene zeer gunstige positie. Zooals dit onder vele primitieve volkeren geconstateerd is (bijv. onder de Toradja's), was de vrouw onder de heidensche Minahassers een persoon van aanzien en invloed. Dit blijkt onder verschillende benamingen voor vrouw, zoooals tetenden ( $\mathrm{Tb} ., \mathrm{Tt}$.) = leunster, kasēndē' $=$ mede-eetster dus gelijkwaardige ${ }^{1}$ ), waaruit Wilken heeft afgeleid dat de Minahassische maatschappij het z.g. moederrechtelijk stadium moet gekend hebben (d. w. z. eene periode waarin de kinderen nog den stam of de horde hunner moeder volgden). Mr. F. D. E. van Ossenbruggen heeft echter in zijne geschriften aangetoond, dat er geen verband tusschen eene gunstige positie van de vrouw en het moederrecht bestaat ${ }^{2}$ ), doch, dat mogelijk het z.g. koophuwelijk of het feit, dat de echtgenoote, in onderscheid van slavinnen en bijzitten, wettige en vrije kinderen voortbracht reeds in de beginstadia van het menschelijk huwelijk de positie der vrouw sterk heeft begunstigd. - In de Minahassa heeft het Christendom en het zeer spoedig aangevatte onderwijs aan meisjes die gunstige positie bevestigd. In den laatsten tijd zijn de Minahassische vrouwen vereenigingen gaan oprichten waarvan de meestbekende zeker wel is de P. I. K. A. T. (Persirakatan iboe kepada anak toemoeroen), die zich verdienstelijk maakte door het oprichten van eene huishoudschool.

Niet altijd echter is de jonge vrouw vrij geweest in de keuze van haar echtgenoot. Zelfs nu nog komt, naar men zegt, vooral in Tonsea en Tomohon, dwang van de zijde der ouders vrij veel voor. Maar gelukkig kan het genoemd worden, dat de zoo verderfelijke kinderhuwelijken ${ }^{3}$ ), de z.g. pesendé'en (Tt.) tot het verleden behooren; de huwelijkswetgeving van 1861, die een bepaalden ouderdomstermijn stelde, heeft daartoe den krachtig-

1) Zie Wilken, I blz. 263 en 378-379. - Zie ook Tendeloo. De toestand der vrouw in de Minahassa in Mededeelingen vanwege het Nederlandsche Zendelinggenootschap deel $17 \mathrm{blz}$. 19. Eene aardige benaming is ook si es a $=$ de andere, de wederhelft.

2) Zie Ethnologisch-juridische beschouwingen over Chineesch erfrecht (Indische Gids 1904 deel 1 blz. 496) en Oor sprong en eerste ontwikkeling van het testeer- on voogdijrecht blz. 27.

s) Zie Graafland, I blz. 462-464, Wilken, I blz. 153, 472 en Tontemboansche Teksten, verhaal no. 136 (Hollandsche vertaling.) 
sten stoot gegeven. Trouwens heden ten dage krijgen de meisjes (bij jongens komt dwang maar weinig voor) al meer en meer recht van medespreken in de keuze harer aanstaande levensgezellen; de ouders die dat recht niet willen kennen, moeten den uitgeoefenden dwang wel eens bekoopen met de hun aangedane schande, dat hun kind door haar minnaar wordt geschaakt. In Tonsea en de hoofdplaats Tondano, doch waarschijnlijk ook elders hoort men van die gevallen.

Men trouwt thans zoowel binnen als buiten zijn eigen stam (eleutherogamie); de huwelijken geschieden echter meestal binnen den eigen stam en voor het huwen van een meisje buiten den stam wordt nog een grooter bruidsschat betaald dan voor een huwelijk binnen den stam (voorbeelden hiervan vindt men in grensnegorijen als Paniki-atas en Paniki-bawah op de grens tusschen Menado en Maoembi). Volgens de adat zijn huwelijken binnen den vierden (soms zesden) graad verboden. Naar Wilken ${ }^{1}$ ) moet dit een overleefsel zijn uit den tijd, dat in de Minahassa de exogamie nog bestond, d. w. z. het verbod om binnen eene groep van aanverwante personen te huwen, eene wet, die volgens de sociologie, al heel oud moet zijn.

Ook erkent het adatrecht gemengde huwelijken van Christenen en Mohammedanen. Dat hierbij als algemeene regel geldt, dat òf de vrouw tot den godsdienst van den man overgaat, zooals Prof. Van Vollenhoven op gezag van Mr. J. H. Carpentier Alting aanneemt ${ }^{2}$ ), ò het omgekeerde, z.ooals door Mr. J. C. Kielstra verondersteld wordt ${ }^{3}$ ), is onjuist. $\mathrm{Er}$ bestaat hiervoor geen algemeene regel. Van Amoerang werden mij drie gevallen vermeld waarbij de man was overgegaan tot den godsdienst der vrouw; in Likoepang waren in negen gevallen de mannen tot het geloof van de vrouw overgegaan, tegen zeventien gevallen waarbij het omgekeerde plaats had.

Het huwelijk is in de Minahassa sedert 1861 kerkelijk, hetgeen den lezer, die weet dat het overgroot deel der bevolking Protestantsch is, wel zal verwonderen. De bekende regeling van Staatsblad $1861 \mathrm{n}^{\circ}$. 38 toch schrijft voor eene huwelijksaangifte bij den controleur van het Binnenlandsch Bestuur (het overbekende "toelis nama», Mal.), vervolgens afkondiging op

1) Wilken 1 blz. 143.

2) Zie van Vollenhoven t.a.p. blz. 335 en Carpentier Alting t.a.p. blz. 149-150

s) Zie Tijdschrift van het Binnenlandsch Bestuur deel 47, 1914 blz. 258-261. 
twee achtereenvolgende Zondagen van den kansel (membatja soerat gebod, Mal.) en huwelijksvoltrekking door den predikant, zendeling of priester, minstens drie etmalen na de laatste afkondiging (di berkati Mal.).

In zijn hierboven meer aangehaald werk heeft Mr. J. H. Carpentier Alting uitvoerig betoogd hoe gebrekkig en onvolledig deze regeling van 1861 is en daarom aangedrongen op de invoering van eene betere, door hem zelf voorgestelde, huwelijkswetgeving waarmede de invoering van een burgerlijk huwelijk gepaard zou gaan ${ }^{1}$ ). Met de wijziging der Regeeringsopvatting ten aanzien van de codificatie van het adatrecht (in de Inleiding van dit hoofdstuk besproken) is van deze voorgestelde huwelijksordonnantie niets gekomen en wacht de Minahassa dus nog steeds op eene zoo noodzakelijke hervorming van dit deel van het burgerlijk recht. Echter zal in het nieuwe voor alle volksgroepen geldend Burgerlijk Wetboek volgens de eigen woorden van den Directeur van Justitie Scheuer in zijn antwoord op eene rede van het Minahassisch Volksraadlid Waworoentoe het Inlandsch Christenhuwelijk waarschijnlijk een burger huwelijk worden ${ }^{2}$ ).

Door de regeling van 1861 en vanwege den invloed van zendelingen, "die vaak, in den beginne althans, alles wat den heidenen nationaal was, daarom alleen ook "heidensch » achtten en dus tegen de oud-nationale gewoonte met kracht streden, (woorden van Carpentier Alting t. a. p. blz. 59), en de nabootsingzucht, die vooral den tot het Christendom bekeerden Inlanders eigen is, zijn vele oude en daaronder ook zeer mooie gebruiken verdwenen.

Voor een juist begrip der hier en daar aangetroffen en nog aan te treffen overblijfselen dier gewoonten, zal eene beknopte beschrijving van de heidensche wijze van huwelijksvoltrekking in dit hoofdstuk niet mogen ontbreken; voor eene gedetailleerde beschrijving verwijs ik naar de uitgebreide litteratuur ${ }^{3}$ ).

1) Zie Carpentier Alting deel 1, 1e stuk blz. 18-22, 54-56 en in het 3e stuk blz. 44-47.

2) Zie Handeiingen van de najaarszitting van den Volksraad in $1918 \mathrm{blz}$. $261-267$.

s) Zie o.a. Dr. J. G. F. Riedel. Alte Gebräuche bei Heirathen, Geburt und Sterbefälle bei den Toumbuluhstämme. (Archiv für Ethnographie deel 7 blz. 89 e. v.); J. A. T. Schwarz. Tontemboansche Teksten. Aanteekeningen blz. 136-137. Verder Carpentier Alting t.a.p. blz. 56 noot 2, Graafland deel 1 blz. 468 en ten slotte speciaal voor de Bantikkers het meergenoemd artikel van P. A. Mandagie. 
Op een vooraf bepaalden dag gaat de bruidegom, vergezeld van familie en kennissen, naar de woning der bruid, alwaar ook hare verwanten en kennissen opgesteld staan om den stoet op te wachten. In dien stoet wordt alles wat van den bruidsschat draagbaar is meegenomen; bij de Bantikkers draagt een jong meisje, dat niet ouderloos mag zijn ${ }^{1}$ ), de bovenvermelde boeto e ra ng. Bij de Tontèmboan was het gewoonte, dat de bruidegom een stuk brandhout en een hakmes medenam; bij de woning van de bruid gekomen, hakte hij het hout in drie stukken en gaf die zijne schoonmoeder als een teeken, dat hij steeds voor het brandhout, dat zijne aanstaande schoonmoeder noodig zou hebben, zou zorgen. Ook van de Tomboeloe' vermeldt Riedel een dergelijk aardig gebruik, dat men helaas! thans nog maar zeer zelden ziet.

Is de stoet de woning binnengetreden, dan wordt de bruidsschat aan de ouders van de bruid aangeboden. Gedurende die plechtigheid moeten onder de Bantikkers de vrouwen hardop lachen (mododdarē) om eventueele onheilspellende vogelgeluiden te overstemmen. Daarop komt de bruid uit haar vertrek te voorschijn en nadat zij haar geliefde sirih en pinang heeft aangeboden wordt er aan een groot feestmaal begonnen, gedurende 't welk de priester (walian) den zegen van de goden inroept en bruid en bruidegom samen eten, terwijl ouden van dagen intusschen den jongelieden wijze levenslessen geven. Bij de Tontèmboan werd aan het feestmaal de kop van een op dien dag geslacht varken gegeten, terwijl dan ook het z.g. mareindeng d.i. het voordragen van zangen door den walian, plaats heeft. Was het mareindeng afgeloopen, dan gingen de moeder en die dochters des huizes, die de wijding tot priesteres hadden ondergaan, rondom het geslachte varken zitten. De walian plengde het drankoffer, daarna werd de lever beschouwd, waaruit de walian voorspellingen deed. $\mathrm{Na}$ afloop van het maal geleidt eene oude vrouw het bruidspaar naar een vertrek waar zij opgesloten worden. Den volgenden dag gaat het paar onder geleide van een(e) priester(es) en eenige familieleden naar den rand der negorij, eene plaats, die in vele streken nog in eere

1) In dit ouderloos zijn, thans zinnebeeld van onschuld en zorgeloosheid, onderkenne men volgens de oorspronkelijke adat, een middel om te voorkomen, dat ook de kinderen van het bruidspaar ouderloos zullen worden, 
gehouden wordt, de ēntē oem banoea (Tb., de steun der negorij) de tanda'mbanoea (Bt., de omheining der negorij) of de pasela (Ts.), waar eenige symbolische handelingen worden verricht. Daarop keert men terug naar de woning van de ouders van den bruidegom. (Alleen bij de Bantikkers keerde men terug naar de woning der bruid). Gedurende dezen tocht weigert de vrouw herhaaldelijk voort te gaan, alleen door extra-geschenken is $z \mathrm{ij}$ te bewegen voort te loopen. Denzelfden onwil toont zij bij de trap van de woning van haar man, bij het binnentreden van het huis, enz. enz. Zelfs weigert zij op dien dag eten van haar echtgenoot aan te nemen, als deze haar niet wat cadeautjes geeft. Hier hebben wij te maken met eene algemeen over de wereld verbreide gewoonte, die zou moeten dateeren uit den tijd, toen de familie der vrouw niet dan tegen behoorlijke vergoeding een lid harer gemeenschap afstond aan de familie van den man.

Eigenaardig was de oude heidensche huwelijksvoltrekking bij de Tonsini in Tonsawang. Ook hier was een feestmaal gebruikelijk; het heet ma'atoe en toont veel overeenkomst met de elders voorheen gebruikelijke en bovenbeschreven huwelijksmalen. Het maal heeft zoowel in het huis der bruid als in dat van den bruidegom op denzelfden dag plaats; na afloop gaat het echtpaar terug naar de woning der bruidsouders, waar de eerste huwelijksnacht wordt doorgebracht en waar men een jaar lang blijft samenwonen. Het merkwaardige is nu, dat hiermede pas eene voorloopige echtverbintenis tot stand is gebracht, een huwelijk op de proef. Blijkt na een jaar, of langer, dat men tot een vaster huwelijk kan overgaan, het z. g. ma'imbat, dan wordt de walian gewaarschuwd. Deze zegent dan eenige paren tegelijk in, hij roept die allen op en laat hen een stuk goed opvouwen en met kapok vullen, terwijl de vrouwen een halssnoer of ook wel een armband (éla'a') als symbool van liefde en trouw krijgen; bij echtscheiding wordt zoo'n armband teruggegeven. De plechtigheid eindigde met een groot eetmaal, dat enkele dagen na het ma'imbat plaats heeft en manambeng heette en drie dagen en drie nachten duurt. Het Christendom heeft zelfs ook in dit hoekje van de Minahassa waar het Heidendom het langst stand hield deze oude gebruiken weggevaagd, en niet alleen onder de Christenen, maar ook onder de Heidenen, is het ma'atoe en het ma'imbat niet meer bekend. 
In het mohammedaansche Ponosakan zijn de oude huwelijksgebruiken het langst bewaard gebleven. Ook hier de gewoonte en de verplichting voor den bruidegom om bij elke mogelijke gelegenheid geschenken (bowohoi) te geven. Komt hij onder helsch lawaai van het dikir en het slaan op de rabana (de trom) binnen, dan moet hij al dadelijk met zijne uitdeeling beginnen aan de muzikanten. Het mohammedaansch huwelijk wordt hier gesloten in de woning der bruidsouders; de bruid is gedurende de voltrekking, die op de gewone mohammedaansche wijze ${ }^{1}$ ) geschiedt, in haar vertrek. Na afloop gaat de bruidegom haar halen en geleidt haar na eenige malen bow ohoi geofferd te hebben, naar den feestdisch. Den volgenden dag gaat het paar met feestgangers naar de woning van den man. De bruid trapt voordat zij dat huis binnen treedt drie malen met ontblooten voet op een paar stukken oud ijzer (o ekoer), waarop hare schoonouders haar een ring aan den vinger steken. Ten slotte wordt nogmaals een feestmaal gegeven.

Het huidige huwelijksceremonieel kent al weinig meer van de bovengenoemde inheemsche gebruiken. Als de bruidsschat naar de familie van de bruid gebracht is en alles goedgevonden is, worden de huwelijksstukken met het dorpshoofd in orde gemaakt. Des Donderdags geschiedt dan het "toelis nama», de huwelijksaangifte voor den controleur. Men rijdt dan in karretjes in westersche dracht - de mannen in rok, de vrouwen in de mooiste Europeesche bruidskleederen - naar de controleursstandplaats. Paartjes die nog al verafgelegen wonen, wachten liever totdat de controleur op dienstreis zijnde in hunne buurt komt, hoewel weer anderen graag geld verspillen aan die tochten naar Menado, Tondano en Amoerang. Een gewoon karretje wordt door bemiddelden al te min gevonden, de autoverhuurderijen verdienen Donderdags een goed duitje aan het heen en weer brengen van «toelis nama-»paartjes. Geschiedt de reis naar de onderafdeelingshoofdplaats reeds met zulk vertoon, de feesten op den dag der huwelijksaangiften en op dien der huwelijksvoltrekking, ja zelfs gedurende de beide daartusschenin vallende Zondagen, zijn niet minder kostbaar; vooral het district Tonsea spant in deze de kroon.

In den vroegen ochtend na den feestnacht, die al zingende

1) Zie Carpentier Alting deel I, 1e stuk blz. 155 e. v.

Dl. 81. 
en dansende wordt doorgebracht, wordt het jonge paar door de bruiloftsgasten naar de woning van de ouders van den man gebracht. In Tonsea wordt nog algemeen door bruidsouders geëischt, dat vóór de bruid de ouderlijke woning verlaat en de andere woning betreedt, haar oudergewoonte extra giften worden gegeven (mapenè'an). Zelfs krijgt bij zulk eene gelegenheid een hooge bruiloftsgast (bijv. een districtshoofd) een geschenk. - In Tomohon en boven-Menado is de geveinsde onwilligheid der bruid nagenoeg verdwenen, maar bestaat nog wel de gewoonte om het jonge vrouwtje wanneer zij reeds de woning van haar man binnengetreden is, bijv. eene sarong en eene kabaja, of een ander cadeautje te geven. In Sili'an (Tonsawang) komt het voor, dat, niettegenstaande het huwelijk op Christelijke wijze is voltrokken en de gehuwden eenige nachten in de woning van de bruid hebben geslapen, zij daarna besluiten naar de woning van den bruidegom te gaan, omdat de bruidsouders hun kind niet willen afstaan en de ouders van den man nog officieel hunne schoondochter moeten komen vragen. Zelfs moet het negorijbestuur wel eens tusschenbeiden komen. De lezer herkent in deze gebruiken overblijfselen van oude, bovenbeschreven gewoonten.

Het jonggetrouwd paar betrekt niet aanstonds een eigen woning, gewoonlijk blijven zij gedurende een jaar bij de ouders van den man - een enkele maal ook om practische redenen, bij de ouders van de vrouw - inwonen; zij krijgen daar een afzonderlijk vertrek. ${ }^{1}$ ). De Bantiksche adat schrijft voor, dat de jonggehuwden bij de ouders der vrouw intrekken; de man moest dan vroeger voor zijne schoonouders zwoegen als een slaaf ${ }^{2}$ ). Die toestand is gelukkig in de laatste jaren veel verbeterd. Het spreekt overigens van zelf, dat bij de andere stammen in de Minahassa het jonge paar verplicht is de ouders in alle werkzaamheden te helpen, terwijl de ouders van hunne zijde verplicht zijn tot onderhoud van de inwonende kinderen.

De nieuwe woning, die door het jonge paar betrokken zal worden, wordt soms door één der ouderparen, soms door beide ouders samen gebouwd. In Kawangko'an bestaat de goede gewoonte, dat een jonge man niet in het huwelijk mag treden,

1) Dit vertrek heeft geen bijzonderen naam, zooals door Mr. Carpentier Alting (zie t.a.p. blz. 60) verondersteld wordt.

') Zie Mandagie t.a.p. blz. 32-33. 
als hij nog niet voor eene echtelijke woning gezorgd heeft; het huis wordt dan gemeenschappelijk bezit, de z.g. harta pendapatan (Mal.), van het echtpaar, hetgeen toch niet altijd het geval is. Slechts wanneer het huis voor gezamenlijke rekening gebouwd is, wordt het als gemeen gewonnen goed aangemerkt; het erf behoort zelden onder de harta pendapatan omdat het doorgaans in het bezit is van een der beide familiën, die den grond niet aan het jonge gezin wenschen af te $\operatorname{staan}^{\mathbf{1}}$ ). Wel zijn als harta pendapatan te beschouwen de uitzet ${ }^{2}$ ), voorts, ook bij tweede en verder huwelijk, alles wat staande het huwelijk wordt verkregen, de opbrengst van ieders eigen goed, ook de vruchten van krachtens versterfrecht of krachtens familiegôedverdeeling verkregen bezittingen. Niet tot de gemeenschap behooren deze beide laatstgenoemde categoriëen van goederen zelve, evenmin de ten huwelijk aangebrachte goederen ${ }^{3}$ ); tevens wordt onder eigen goed begrepen het in gebruiksrecht gegeven aandeel in den communaal bezeten familiegrond.

Is de huwelijksband in de Minahassa hecht? Aan een beslist antwoord op deze vraag waag ik mij liever niet. Mr. Carpentier Alting verklaarde in 1902, dat de huwelijkstrouw bij de Mohammedanen in de Minahassa "onbetwist veel grooter is dan bij de Christenen ${ }^{4}$ ). Mijne vele zegslieden hadden de meest uiteenloopende antwoorden, ik concludeerde daaruit dat vooral in Rembokken, Tomohon, Tombariri, Tonsea en enkele negorijen boven Menado de huwelijksband zeer los moet zijn. In de districten Tonsea en Tomohon komen de meeste echtscheidingszaken voor den landraad.

Vele zijn de oorzaken tot echtscheiding: oneenigheden, overspel, luiheid van een der echtgenooten, kinderloos huwelijk, mishandeling, afwezigheid wegens vrijheidsstraf, enz. Het spreekt van zelf dat het ongeschreven gewoonterecht reeds van ouds eenvoudige wijzen van echtscheiding regelde. Het eenvoudigst was wel het minnelijk uiteengaan zonder meer. Men heeft dit in Tomohon vroeger in het Moluksch Maleisch genoemd "ber-

1) Mr. Carpentier Alting t.a.p. blz. 72 is echter van oordeel, dat huis en erf als harta pendapatan zijn te beschouwen.

2) Behalve bij de Bantikkers (zie Mandagie t.a.p. blz. 33).

s) Ook in het district Tonsea, waar volgens eene veronderstelling van prof. van Vollenhoven (t.a.p. blz. 338) het aangebrachte goed in het gemeene zou opgaan.

4) Zie Carpentier Alting t.a.p. blz. 76 en 77 vooral noot 3 op blz 76 . 
tjerai kooi dan mèdja» (van bed en $\mathrm{tafel}$ gescheiden) woorden, die zonder twijfel uitvindsel van een landsraadvoorzitter of, zooals Mr. Hekmeyer ${ }^{1}$ ) veronderstelt, van Roomsch-Katholieken oorsprong zijn. Deze wijze van scheiden geschiedde ten overstaan van het dorpshoofd of voor twee oudsten, die daarvoor eene vergoeding kregen. - In een ander geval was de vrouw genoodzaakt weg te loopen, soms ook wel was dit een middel om geld van den man te krijgen, want de man kon de vrouw alleen door betaling van een losgeld in zijne woning terugzien (eene nog niet geheel verdwenen gewoonte). Bij de Bantikkers, waar de huwelijksband nu nog, zooals wij gezien hebben, niet te hecht is, kon de man wel eens spoedig na den huwelijksdag er genoeg van krijgen, hij verliet het huis zijner schoonouders na eerst zijne vrouw de poto, een bedrag van twee soekoe ( $f 0.78$ ) gevraagd te hebben; had hij berouw van zijne daad en wilde hij weer terugkomen, dan moest hij met behulp van eene groote schadeloosstelling eigenlijk opnieuw trouwen ( $\mathrm{ma}$ saoere) en opnieuw een bruidsschat betalen, een gebruik, dat thans nog maar zelden toepassing vindt ${ }^{2}$ ). - Als derde wijze van ontbinding van het huwelijk noemt Mr. Carpentier Alting de verstooting van de vrouw. Het zeer eenvoudige verstootingsformulier was dan: "ga naar beneden ${ }^{3}$ ).

Sedert 1861 kan het in de kerk voltrokken huwelijk alleen wettig door den landraad ontbonden worden, een - door den landraad zelf uitgevonden - regel, die niet alleen onlogisch, doch ook niet in overeenstemming met de adat is. Men wendt zich dan ook alleen tot den landraad, wanneer de verdeeling van de harta pendapatin niet in der minne kan geschieden of men opnieuw wil gaan trouwen.

Voor de financiëele gevolgen van de scheiding moeten, volgens Mr. Carpentier Alting de volgende adatregelen bestaan hebben:

1. $\mathrm{Bij}$ minnelijk uiteengaan werden de gemeene goederen in twee gelijke deelen verdeeld, dan wel, waar dat gewoonte was, den man $\frac{2}{3}$, de vrouw $\frac{1}{3}$ toegekend.

2. Had de vrouw door wangedrag aanleiding gegeven tot de verstooting dan ging haar recht op de goederen der gemeenschap

1) Zie zijn „De ontwerpen tot regeling van het privaatrecht voor de Inlandsche bevolking in de Minahassa" (Indische Gids 1904 deel 2, blz. 104).

2) Nadere bijzonderheden vermeldt Mandagie t.a.p. blz. 35-36.

3) Zie Carpentier Alting t.a.p. blz. 76 en Graafland I blz. 470. 
teloor; had echter de vrouw geen schuld aan hare verstooting, dan behield zij haar recht op bedoelde goederen en kreeg zij niet zelden bovendien nog eene schadeloosstelling van haar man.

3. Veroorzaakte wangedraging van den man het wegloopen der vrouw, dan kromp zijn aandeel aanmerkelijk in ten bate der vrouw.

4. Verliet de man de echtelijke woning, dan verbeurde hij alle aanspraak op de goederen der huwelijksgemeenschap.

Precies volgt de landraad deze regelen niet. Gewoonlijk wordt de harta pedapatan eenvoudig in twee gelijke deelen verdeeld.

Tot teruggave van den bruidsschat is de vrouw, noch hare familie, verplicht, wel echter de bruid en de bruidsverwanten, wanneer het meisje de trouwgelofte breekt en haar liefde aan een anderen man schenkt.

Voor de Mohammedaansche verstooting (die bijna nooit door herroeping wordt gevolgd), de voorwaardelijke echtscheiding door wijkmeester of kamponghoofd met den imām of door den imām alleen, verwijs ik naar Mr. Carpentier Alting's meergenoemd werk (t. a. p. blz. 159 e. v.).

Voor de huwelijksontbinding door den dood gelden dezelfde regelen als voor huwelijksontbinding krachtens minnelijk uiteengaan; echter met dit verschil, dat wanneer de echt kinderloos is, de goederen der gemeenschap heel dikwijls onverdeeld blijven en aan de(n) overlevende komen. Zijn er daarentegen nog minderjarige kinderen, dan beheert de langstlevende ouder voorloopig de goederen, aangezien hij of $z \mathrm{ij}$ toch volgens de adat de voogdij uitoefent. Het gewoonterecht kent geen regeling van voogdij over minderjarige weezen; toen de familieband nog hecht was, was voor eene bijzondere behartiging hunner belangen weinig reden, de familie nam die zorgen eenvoudig op zich; eigen vermogen en eigen rechtsbelangen hadden die kinderen ook niet, alle sterfboedel van hunne ouders kwam immers na den dood aan de familiegemeenschap. Doch nu de familieband al meer en meer gaat verslappen, hapert er dikwijls veel aan de wijze waarop de voogdij wordt uitgeoefend. Eene andere regeling hiervan is zeer noodzakelijk ${ }^{\mathbf{1}}$ ).

1) Zie rede van Wawo-Runtu in den Volksraad, najaarszitting 1918, Handelingen blz. 263 en Mr. Carpentier Alting t.a.p. tweede gedeelte blz. 1-3; zijne ontwerpen omtrent eene regeling van de voogdij vindt men op blz. 18 e.v. 
Zwangerschap, geboorte, na amgeving.

Gedurende de zwangerschap heeft de vrouw, en zelfs ook haar echtgenoot, volgens het bijgeloof van alle volkeren over de geheele wereld, zich aan allerlei verbodsvoorschriften te onderwerpen. Verschillende spijzen, dranken en handelingen zijn dan voor haar taboe, een Polynesisch woord, dat in de wetenschap der volkskunde burgerrecht heeft gekregen en dat door *onaantastbaar" of "verboden» kan worden vertaald; in de Minahassische. talen heet het posan. Die taboe-voorschriften hebben uitteraard de bedoeling de in den moederschoot rustende vrucht te vrijwaren voor allerlei slechte invloeden.

Hebben wij, bij de beschrijving van het Minahassisch huwelijk gezien, hoe gauw hier de inheemsche Christenbevolking de uiterlijke gewoonten van den Westerling overneemt, begrijpelijk is het, dat aan het innerlijk geloof een Christendom van een kleine eeuw nog heel weinig veranderd heeft. Verwonderlijk is dat in geenen deele als wij weten, dat nu nog in verschillende streken van het platteland in Holland het bijv. eene algemeene verbreide meening is, "dat het zeer verkeerd is gedurende de zwangerschap waschgoed op te hangen, onder een drooglijn door te loopen, met de armen boven het hoofd te slapen» (Prof. dr. J. Schrijnen, Nederlandsche Volkskunde, deel I blz. 212-213). Algemeen is dan ook over de geheele Minahassa het geloof aan allerlei bovenbedoelde verbodsvoorschriften voor de aanstaanden vader en de moeder. De laatste mag niets zien dat schrikwekkend is, bijv. een dier dat geslacht wordt, of een lijk, zij mag niet voor een open deur blijven staan, opdat het kind niet met moeite ter wereld zal komen; om die reden moet zij op straat doorloopen, niet stil blijven staan om te praten; bamboevlechtwerk mag zij niet afmaken, evenmin mag zij, of haar man in touw of draad of iets anders een knoop maken, of iets vastbinden. Bang zijn beiden ook om een snoer of iets dergelijks om den hals te dragen, anders zou het kind den navelstreng om $z$ ij $n$ hals kunnen krijgen. De man mag geen kain over zijn schouder dragen of een touw om zijn lichaam slingeren. Man en vrouw mogen gedurende de zwangerschap niet twisten en de vrouw vooral mag niemand een kwaad hart toedragen. Gedurende de geheele zwangerschap is het den man verboden zich het haar te knippen, of te laten knippen, uit vrees, dat het 
kind zijn heele leven lang kaalhoofdig zal blijven ${ }^{1}$ ); om dezelfde reden mag de klapperdop waaruit men drinkt, van buiten niet glad gemaakt worden. De beide echtgenooten mogen niet met lange teugen drinken en vooral niet uit iets, dat eene smalle opening heeft; evenmin is het hun geoorloofd aaneengegroeide vruchten te eten, opdat geen tweelingen geboren worden. Verder mag de man niet iets scheef afsnijden; geen gat maken in de tusschenschotten van de bamboegeledingen, anders zou het kind veel in bed urineeren. Wil hij palmwijn of water in een bamboe halen, zooals dat gewoonlijk in de Minahassa geschiedt, dan mag hij de bamboe met het touw slechts over zijn schouder dragen, en niet met het touw over den schouder en onder den oksel door.

Er zijn geen bepaalde maanden van de zwangerschap, die volgens het volksgeloof eenige beteekenis hebben. Als het oogenblik van de bevalling gekomen is, dan wordt eene oude vrouw geroepen, die bij de verlossing behulpzaam is. Gediplomeerde vroedvrouwen of verloskundigen zijn er nog maar al te weinig; de genoemde vrouwenvereeniging P.I.K. A. T. heeft in den laatsten tijd nog eens op meerdere hulp van Landswege aangedrongen. De wijze waarop de «doekoens» uit de negorij de bevalling leiden is dan ook hoogst primitief en dikwijls zeer gevaarlijk voor de kraamvrouw; komen er complicaties bij, dan bezwijken veelal moeder en kind tengevolge van de ondeskundige behandeling.

Gedurende de bevalling moeten alle deuren, vensters, koffers, kisten, enz. opengemaakt worden, opdat de verlossing gemakkelijk van stapel zal loopen. De doekoen wrijft de kraamvrouw met klapperolie over haar buik; een drastische maatregel om de bevalling te vergemakkelijken is het binden van een kain om den buik. Tevens moet de kraamvrouw allerlei drankjes slikken, waaronder, naar men mij mededeelt, ook een aftreksel van versleten kleederen van naaste familieleden!

Als het kind ter wereld is, wordt de navelstreng doorgesneden, doch dit mag, evenals op Java, niet met een mes of schaar geschieden, doch met een scherp bamboelatje (tētēwa' in het Tb. en tětěwa' in het Tt.) De navelstreng en de placenta worden in een aarden pot (in Ratahan in een bamboekoker) onder het

1) Dit is, naar dr. Adriani opmerkt, meer eene „moderne" opvatting. Oorspronkelijk mocht de aanstaande vader het haar niet laten knippen, omdat hij daardoor levenskracht zou verliezen. 
huis begraven. Vroeger ging dit met eenige plechtigheid gepaard ${ }^{\mathbf{1}}$ ), thans niet meer. Na de bevalling wordt de vrouw verwarmd. Men maakt onder natgemaakte steenen een vuurtje, dat weinig rook geeft; daarboven ligt de kraamvrouw op een bank in een halfzittende houding zóó, dat de lendenen goed verwarmd worden. Men vertelt mij, dat de bedoeling hiervan is de vrouw te laten zweeten, doch gelijk $\mathrm{Mr}$. Carpentier Alting ${ }^{2}$ ) opmerkt, is het zeer waarschijnlijk de oorspronkelijke opvatting geweest, dat het vuur de booze geesten moest weren, eene alom verbreide meening onder alle volkeren van de wereld. Het kleine kind wordt na gebaad te zijn, drie keer heen en weer gewiegd ${ }^{3}$ ) en krijgt vervolgens ook allerlei drankjes. Zoolang de moeder het kind nog zelf voedt, mag ze bepaalde spijzen niet eten o.a. geen zoetigheid, geen vet, geen eten dat met klappermelk bereid is. Op ongeregelde tijden geeft $z$ ij het kind de borst, dikwijls alleen maar om het kind te sussen. De pasgeborenen worden in een eigenaardige wieg, bestaande uit een sarong die aan beide einden saamgebonden en opgehangen is aan een spijker aan den zolder, te slapen gelegd.

Ik mag niet nalaten te vertellen, dat gedurende de bevalling aan de wanden van de slaapkamer le m on soeangie (Mal.) (Citrus limetta Rissa) en lidi's (Mal.) (de nerven van palmbladeren) worden opgehangen. Het zijn de afweermiddelen tegen de over den geheelen Indischen Archipel zoo bekenden en gevreesden geest Pontianak, de geest van eene in het kraambed gestorven vrouw, hier gewoonlijk voorgesteld als eene door de lucht vliegende heks met loshangende haren en een groot gat in den rug of in den buik, die de kraamvrouw de moedervreugde niet gunt en dus uit de kraamkamer geweerd dient te worden. Niet alleen heeft $z$ ij het begrepen op de aanstaande moeders, doch ook op de vaders, die zij, naar men zegt, naar de schaamdeelen grijpt. Is er in eene negorij eene vrouw tengevolge van de bevalling of zelfs maar gedurende de zwangerschap overleden, dan waagt zich niemand 's avonds op straat, tenzij met

1) Zie Tontemboansche Teksten. Hollandsche vertaling blz. 271-272.

2) T.a.p. deel 1 blz. 5 noot 2. Ook in Atjeh bestaat de gewoonte van het verwarmen der kraamvrouw.

s) Riedel merkt in zijn "Alte Gebräuche" op, dat dit heen en weer wiegen geschiedt in de richting van de Toehoer in Tana', het grensgebergte tusschen Bola'ang-Mongondou en de Minahassa, de verblijfplaats van het eerste menschenpaar Loeminoe'oet en Toar. 
een flambouw of drie lidi's. Vreest men dat de pontianak om het huis rondwaart, dan verjaagt men haar het best door aarde of scherven naar buiten te gooien, of buiten versleten goed te verbranden. Om te voorkomen dat eene in de kraam overleden vrouw pontianak wordt, moet het lijk zoo behandeld worden, dat het zich niet zal kunnen bewegen. In den palm van elke hand en onder elken oksel wordt een ei geplaatst, in de toppen der vingers worden spelden gedrukt, het hoofdhaar wordt over het gezicht verspreid ${ }^{1}$ ). De meening van Schwarz dat het pontianak-geloof hier niet oorspronkelijk heeft bestaan, doch door Mohammedanen is ingevoerd is mogelijk wel juist mij werd hetzelfde in Katahan medegedeeld - doch merkwaardig is het dan toch wel dat een specifiek Indonesisch bijgeloof in de Minahassa zulk een ingang heeft gevonden en in allerlei districten in zijne uitingen zoo wonderlijk overeenkomt.

De pontianak waarvoor in de inheemsche talen geen eigen woord bestaat, mag niet verward worden met de songko' (Tt.), d. i., een man of vrouw, die de angstwekkende macht bezit zich des nachts het hoofd met de ingewanden uit het lichaam te trekken en daarmede door de lucht te vliegen en dan overal waar dat mogelijk is den menschen het bloed en de lever uit te zuigen. Hoort men des nachts zijn onheilspellend geluid: "pok, pok», dan moet men fluks op zijne zijde gaan liggen en niet met open mond slapen. De lezer herkent in dit volksverhaal wederom het over de geheele wereld bestaand vampyrgeloof ${ }^{2}$ ).

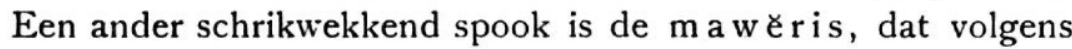
Schwarz een mythisch monster moet zijn. De maweris heeft het niet speciaal begrepen op zwangere vrouwen, over het algemeen wordt hij door een ieder zeer gevreesd. Hoort men zijn geluid: wěris, wěris en vliegt hij boven het huis dan zal binnenkort iemand van het gezin sterven. Deze kwade invloed is ook af te weren met lemon soeangi of lidi's, ook door eene, pajong of een blad van de woka (Livistona rotundifolia) boven het hoofd te houden of luide te hoesten, vooral als men over een brug loopt of rijdt.

1) Zie Tontemboansche Teksten, vertaling blz. 160 en vergelijk voor andere streken waar geheel dezelfde voorzorgsmaatregelen worden getroffen Wilken deel III blz. 225 en Alb. C. Kruyt, Het animisme in den Indischen Archipel blz. 246 e.v.

2) Zie Tontemboansche Teksten blz. 161-162 en de daar vermelde litteratuur over dit onderwerp. 
Feestelijkheden bij of na de geboorte komen onder de Christenen zelden voor. Het plechtig vieren van het z.g. irojor si oki (Tb.) ook wel soemosor si oki of in het Tt. roemojor si toja'ang, dat door Riedel en Schwarz uitvoerig is beschreven ${ }^{1}$ ), schijnt nog in Kawangko'an, Rembokken en in Tonsea (iroros si rinté) onder de weinige heidenen voor te komen. De woorden beteekenen: het jonge kind (voor het eerst) de huistrap afbrengen; op den vijfden of zesden dag na de geboorte wordt het inderdaad de trap af gedragen. Gewoonlijk brengt de moeder of de "vroedvrouw» gevolgd door slechts twee of drie oude vrouwen, soms ook wel door een stoet van familieleden en kennissen het naar een 'bron of beekje in de buurt van de negorij (vroeger onder de Tomboeloe', volgens Riedel, naar de algemeene dorpsofferplaats), waar het wicht wat water over zijn hoofdje gegooid wordt terwijl ook de anderen hun gezicht en voeten natmaken; dit alles heeft geen andere bedoeling dan ziekten en andere slechte invloeden weg te spoelen. In Tonsea moeten de begeleidsters verschillende voorwerpen z. a. een kralensnoer, een gouden haarpen of een gouden ring, een ronden steen en een klein langsa-plantje meenemen, die zij boven het hoofd van het kind houden, wanneer het met water besprenkeld wordt.

Besnijdenis was onder de Minahassische heidenen niet onbekend, het laatst schijnt zij gedurende den Tondanoschen oorlog (1809) toegepast te zijn. Voor bijzonderheden omtrent de wijze waarop deze operatie geschiedde verwijs ik naar de beschrijvingen van Schwarz en Graafland ${ }^{2}$ ).

In de plaats van het roemojor si oki is de doop gekomen (di baptis of di permandian, Mal.). Deze geschiedt op de gewone wijze op een voorafbepaalden Zondag door den hulpprediker of den Inlandschen godsdienstleeraar. Vaders en moeders met familieleden met de doopgetuigen komen dan allen op hun mooist uitgedoscht in de kerk; na de toespraak van genoemden voorganger houden de moeders één voor één hun kind ten doop. In den namiddag heeft een eenvoudig feestje plaats.

Vroeger was ook de dag waarop het kind zijn naam gegeven

1) Zie Riedel t.a.p. blz. 97 e.v., Schwarz, Tontemboansche T'eksten blz. 271 en Graafland I blz. 451 e. v.

2) Zie Tontemboansche Teksten blz, 511 en Graafland I blz. 462. 
werd, een feestdag. De gebruiken die men toen toepaste, worden nu nog onder de heidenen aangetroffen, o.a. in Ratahan; daar is het gewoonte om op den dag der naamgeving een varken te slachten, uit een onderzoek van de lever kan de walian zeggen wat de toekomst voor het kind in haar schoot verborgen houdt; met het bloed worden borst en voorhoofd van het wicht besmeerd, daarop volgt een feestmaal met de familieleden waarbij de walian o.m. het kind eten in den mond steekt, van één tot negen telt en na "negen" gezegd te hebben den naam van den jongen wereldburger noemt ${ }^{\mathbf{1}}$ ).

Gewoonlijk werd en wordt nog bij het doorsnijden van de navelstreng het kind een naam gegeven, vroeger onder het Heidendom door de(n) walian, thans door een oud familielid of den vader; die naam is meestal een inheemsche, van een der heidensche voorouders van het kind; later bij den doop wordt pas een Christennaam, vaak een Bijbelsche, doch ook wel andere als Jan, John, George, Maximiliaan, enz., gegeven. Het voeren van 'vans , (in het Moluksch Maleisch zegt men "vam») is sedert de bekeering tot het Christendom algemeen en zelfs onder de Mohammedaansche bewoners van Ponosakan in zwang. Deze "vam" is gewoonlijk de aloude naam van den eersten Christen uit de familie. De Heidenen hadden vroeger slechts één naam; vandaar dan ook de juistheid der opmerking van Prof. Wilken, die eene geheele monografie wijdde aan dit onderwerp ${ }^{2}$ ), dat niet de familie- maar de voornaam de hoofdnaam is. Hoe weinig de Christennamen in enkele gevallen voor de menschen leven, blijkt wel uit het feit, dat sommigen hun geheele leven door bij hun inheemschen kindernaam genoemd worden. Het veranderen van voornamen komt een doodenkelen keer voor, bijvoorbeeld ingeval een kind in zijn prille jeugd erg ziekelijk is, dan geeft men het een naam van een verafgelegen land, met de bedoeling de ziekte daarheen te bannen. Eigenaardig is de gewoonte, die men mij uit Ratahan mededeelde, om de kinderen dorpsnamen te geven wanneer zij een groote nalatenschap van hunne ouders te verwachten hebben. Zelden, eigenlijk nooit, wordt het kind naar zijn vader of moeder

1) Men zie voor uitvoerige bijzonderheden omtrent het offerfeest bij de naamgeving Tontemboansche Teksten blz. 271, Riedel t.a.p. blz. 99 en Graafland I blz. 454.

3) "Iets over de naamgeving bij de Alfoeren van de Minahassa" in Wilken I blz. 101 e. v. 
genoemd, in Ratahan is het adat het eerste kind den inheemschen naam van een der voorouders van vaderszijde, het tweede den naam van een der voorouders van moederszijde te geven. Ook de Christennamen ( $\mathrm{n}$ a m a s ̌r a n i Mal.) worden niet ontleend aan de voornamen van moeder of vader, dikwijls ook niet eens aan die van familieleden; den Minahasser is die Westersche gewoonte nog vreemd. Komt gedurende de geboorte van een kind juist een hooge autoriteit in de negorij, dan draagt het soms den achternaam van dien autoriteit; zoo zijn voornamen als Jellesma, Ulfers, Ples, enz. niet onbekend. Natuurlijk zijn onder zoo Nederlandschgezinde Minahassers de voornamen van de leden der Koninklijke familie in gebruik, zelfs zijn er, die Hertog Hendrik of Koning heeten.

De gewoonte van ouders om zichzelve naar den naam van hun eerstgeborene te noemen komt nog steeds voor ${ }^{1}$ ). De vader noemt zich dan bijv. in het Tt. a ma' ni Maria, en wordt ook door zijne negorijgenooten aldus aangesproken. De volkenkunde heeft deze merkwaardige gewoonte teknonymie genoemd; zij moet dateeren uit den tijd toen het vaderschap nog onzeker was, het kind dus bij zijne moeder bleef, doch de feitelijke vader het als het zijne wilde erkennen om het zijn nalatenschap te kunnen verzekeren. ${ }^{2}$ )

Uit het voorgaande blijkt genoegzaam, dat de Minahassa reeds lang rijp is voor een burgerlijken stand. Herhaaldelijk is op invoering daarvan aangedrongen, zelfs ook van inlandsche zijde ${ }^{3}$ ), doch tot nogtoe zonder resultaat. Evenmin is het door $\mathrm{Mr}$. Carpentier Alting voorgestelde ontwerp van een reglement op den burgerlijken stand ooit in het Staatsblad verschenen. ${ }^{4}$ )

$\mathrm{Nu}$ moet men zich nog steeds behelpen met geboorteregisters van negorijhoofden, die ook verplicht zijn aanteekening te houden

1) Zie Wilken's aangehaald opstel t.a.p. blz. 106.

- ?) Zie over deze belangwekkende gewoonte Wilken I, blz. 109-111; 283-285 en de litteratuur opgegeven door Mr. F. D. E. van Ossenbruggen op blz. 100 van Wilken I. Dr. Adriani merkt op, dat de verklaring van Prof. Wilken onjuist is. De teknonymie heeft naar zijne meening geen andere beteekenis dan het vermijden van het noemen van den eigen naam van vader of moeder daar het noemen van den eigen naam van ouds, na den kinderleeftijd, verboden was.

3) Zie Adatrechtbundel III, blz. 135 e. v.

4) Zie Carpentier Alting I 1e stuk blz. 1-47., 2e stuk blz. 84 e.v, en $3 e$ stuk blz. 117 e.v. 
van voorgenomen huwelijken en sterfgevallen (op de nauwkeurigheid van deze staten valt natuurlijk veel aan te merken); voorts heeft men voor de Christenen nog doopregisters die echter ten opzichte van den dag van geboorte niet altijd betrouwbaar zijn; en de registers van de ingezegende huwelijken; op het controleurskantoor een register van huwelijksaangiften (dikwijls onvolledig of in het ongereede geraakt) en ten slotte ter griffie van den Landraad de gegevens omtrent echtscheidingen. Hoe gebrekkig is dit alles nog!

Het gaat er echter naar uitzien, dat binnen eene niet al te verre toekomst, de Minahassa eindelijk een behoorlijken burgerlijken stand krijgt. Op de tweede gewone zitting van den Volksraad is door den Directeur van Justitie in antwoord op een desbetreffende vraag van het Minahassisch lid Wawo-Runtu geantwoord, dat de invoering van een Inlandschen burgerlijken stand in de Minahassa overwogen zal worden. Nu de nuttige instelling reeds voor de Chineezen bestaat en de Regeering voornemens is haar ook op Java, althans voor een deel der bevolking, in te voeren, is het werkelijk niet te vroeg thans spoedig met de Minahassa te beginnen.

Erkenning van kinderen en adoptie.

Natuurlijke kinderen dragen den naam van de moeder zoolang zij niet erkend zijn. De Minahassische adat kende het onderzoek naar het vaderschap reeds van ouds en achtte het zelfs eene verplichting voor de familie van de ongehuwde moeder ${ }^{1}$ ). Blijkt eene ongetrouwde vrouw zwanger te zijn, dan trachten eerst de ouders te weten te komen wie de zwangerschap heeft veroorzaakt; soms is hulp van oudsten van de familie of uit de negorij noodig, en omdat de vrouw, wanneer zij ongetrouwd blijft, niet aan het avondmaal mag deelnemen, is bemoeienis van de voorgangers der kerkelijke gemeente om den verwekker van het kind tot trouwen te bewegen, niet zeldzaam. Merkwaardig is de wijze, waarop de vader het buitenechtelijk kind poogt te erkennen. Zoodra het kind geboren is, stuurt hij de moeder luiers of doopkleertjes, ook wel katoen, rijst of brandhout. De symbolische zin dezer giften is duidelijk: wit katoen, om het kind te kleeden, rijst om het te voeden en brandhout om de kraamvrouw te

1) Zie Riedel t.a.p. blz. 93. 
verwarmen. Eene dergelijke erkenning noemt men in het algemeen liliko er (Tb.), didikoet (Ts.) of wiwijo (Tt.), hetgeen beteekent: de sarong waarin een kind gedragen wordt. Wanneer de ouders geregeld samenleven (het z.g. "bakoe piara») is eene dergelijke erkenning niet noodig, wel bijv. wanneer de man overspel pleegt. Dit delict was vroeger al eene zware overtreding van het gewoonterecht; de overspelige man moest zijne eigen vrouw een zoengeschenk geven (nu niet meer), en werd in de negorij ten aanschouwe van eene joelende menigte rondgeleid, terwijl de overspelige vrouw door haar man mocht gedood worden ${ }^{1}$ ). Ook is erkenning noodig wanneer man en vrouw na de conceptie elkander verlaten en eene nieuwe huwelijksverbintenis aangaan. De Minahassische adat n.l. kent geen verbodstermijn binnen welken de echtgenooten na echtscheiding niet opnieuw mogen trouwen, alleen de Moslims houden zich aan den in de Mohammedaansche wet voorgeschreven iddah-termijn. Gaat men nu in het bovengenoemd geval een tweede huwelijk aan binnen negen maanden, dan kan het reeds gedurende het eerste huwelijk verwekt kind bij de geboorte twee vaders hebben. De natuurlijke vader werd in het Tb. genoemd ama' minontol oen toemer = de vader, die het brandhout heeft gedoofd, in het Bantiksch heet hij $\mathrm{i}$ a ma soe $\mathrm{maboe}=$ de vader voor God ${ }^{2}$ ). Onder de Bantikkers is het in zulke gevallen gewoonte, dat de gescheiden echtgenoot voor twee getuigen verklaart, dat hij en niemand anders de vader zal zijn van het binnen kort door zijne gewezen vrouw te baren kind. Men noemt dit manoeraoe bahiga (eene verklaring achterlaten) ${ }^{3}$ ).

De erkening wijst evenals de zooeven vermelde teknonymie op een vroegeren overgang van het moederrechtelijk naar het vaderrechtelijk stadium. Het was een middel voor den man om in den tijd, toen samenleving van man en vrouw nog zelden voorkwam en de verwekker van het kind bijna nooit bekend was, zijne vaderrechten te doen gelden. Tijdens het patriarchaat (d.w.z. het tijdperk waarin de kinderen uitsluitend de familie van den man volgen) was de erkenning noodig wanneer de vrouw op het tijdstip der geboorte van haar kind weer met een

1) Zie Riedel. De Minahassa in 1825 in het Tijdschrift van Indische Taal-, Land. en Volkenkunde deel 13 blz. 458.

2) Zie Mandagie t.a.p. blz. 38.

s) Zie Mandagie als boven. 
anderen man gehuwd was; dan moest de eigen vader de rechten, die den nieuwen man krachtens het huwelijk toekwamen, vernietigen. En nog thans in het ouderrechtelijk stadium bestaat deze wijze van erkenning, en het ware te wenschen dat niet bewaarheid zal worden de veronderstelling van Mr. Carpentier Alting, dat er zich meer en meer een streven openbaart tot afschaffing van "dit aantrekkelijk oud-Alfoersch rechtsinstituut» ${ }^{1}$ ).

In allen gevalle heeft de wetgever bij het ontwerpen van de bovengenoemde huwelijksordonnantie geen rekening gehouden met deze adatregelen. Die regeling maakte voor het eerst een verschil tusschen wettige en onwettige kinderen, dat tevoren nooit bekend was, verder liet zij geen wettiging van in overspel en bloedschande - vermoedelijk een aan den Minahasser oorspronkelijk onbekend begrip ${ }^{2}$ ) - geteelde kinderen, bij het huwelijk toe; bovendien was omtrent de erkenning zelve niets geregeld. Ook ten deze is door Mr. Alting een betere adatscodificatie voorgesteld. ${ }^{3}$ )

De erkenning van buiten echt verwekte kinderen mag niet verward worden met het gebruik, dat de Europeanen in de Minahassa gewoonlijk adoptie noemen: mékioki of itatèr sé oki' karengan Tb. (geschaard worden onder de eigen kinderen), m๕kianak of wat meer in de spreektaal bekend is, ngaranan Tt. en mengara ana' Bt., maar wat eigenlijk in het geheel geen adoptie is. Immers wat verstaat men eigenlijk onder adoptie? Volgens Mr. F. D. E. van Ossenbruggen: "algeheele opname in de eigen familie van den adopteerende met het doel om de familie voor ondergang te behoeden.» Andere geleerden geven aan het woord eene ruimere beteekenis n.l. het aannemen van kinderen als eigen kinderen; de aangenomenen worden dan geheel in de familie van den adoptant opgenomen, alle verwantschapsbanden met zijne eigen familie worden daarmede verbroken. Voorbeelden van deze wijze van adoptie moet men zoeken onder de Toradja's, de Dajaks, Javanen, Gowareezen.

Wat men in de Minahassa adoptie noemt, valt, zoo als wij straks zullen zien, onder geen dezer beide definitie's. Evenmin kan zij gerangschikt worden onder - noch, naar mijn oordeel,

1) Zie Carpentier Alting deel I blz. 8-9.

2) Zie Carpentier Alting deel I blz. 9-10.

3) Zie Carpentier Alting deel I blz. 20 e.v. en de toelichting in deel I $3 e$ stuk blz. $1-39$. 
zooals prof. Steinmet\% meent ${ }^{1}$ ), haar oorsprong hebben in de z.g. "fosterage» d.w.z. de gewoonte om kinderen in vreemde familie's op te voeden op initiatief van de natuurlijke ouders. $\mathrm{Z}_{\mathrm{ij}}$ is echter, zooals door mr. Carpentier Alting voor het eerst is aangetoond, geen instituut van verwantschapsrecht, doch eenvoudig een vermogensrechtelijke overeenkomst tusschen twee personen, aan wie prof. van Vollenhoven de zeer juiste benamingen van zorgtrekker en zorggever gegeven heeft. - Die overeenkomst kan aangegaan worden tusschen personen van gelijken leeftijd en uit welke familie ook (alleen in Ratahan waar het verzorgingscontract weinig voorkomt, uit wederzijdsche familie); ook tusschen ongehuwden van beide seksen (getrouwden behoeven tot aangaan van dergelijke overeenkomsten de toestemming van de(n) echtgenoot); zelfs kan een jongere een oudere als zorggever aannemen.

Intrekking van de overeenkomst is natuurlijk mogelijk doch, met uitzondering van Bantik, slechts van de zijde van den zorgtrekker, bijv. wanneer de andere partij hare verplichtingen niet nakomt, zich onbehoorlijk gedraagt. Onder de Bantikkers kan het ook in de macht van den zorgtrekker liggen om de overeenkomst op te heffen. In dit laatste geval moest de zorgtrekker aan den zorggever teruggeven de paradé, d. i. een geschenk (meestal bestaande uit lijnwaden, halssnoeren, ringen of gouden nagels) als uiterlijk teeken van het totstandkomen der overeenkomst, ook bij andere stammen welbekend, ${ }^{2}$ ) doch thans nog maar zelden voorkomend.

Natuurlijk moest in een tijd, dat nog niemand de schrijfkunst machtig was (de Minahassers bezitten geen eigen schrift), de overeenkomst totstandkomen in eene bijeenkomst van naaste familieleden en (vooral) het dorpsbestuur, bezegeld met een gezamenlijk maal met offerplechtigheden ${ }^{3}$ ). Thans echter gaat het op moderner - niet altijd betere - wijze: met behulp van eene soerat pengakoean (Mal.), een op schrift gesteld en door beide partijen onderteekend contract.

Wat is nu de inhoud van de overeenkomst? De zorgtrekker

1) Zie zijn opstel: De "fosterage" of opvoeding in vreemde families (Tijdschrift ran het Koninklijk Aardrijkskundig Genootschap 1893.)

2) Dat ook dit erkenningsteeken lilikoer, wi wio of didikoed zou heeten wordt door velen ontkend:

s) Zie N. Ph. Wilken. De godsdienst en godsdienstplechtigheden der Alfoeren in de Minahassa op het eiland Celebes. (Tijdschrift van Nederlandsoh-Indië 1849,2 e deel). 
is verplicht zijn zorggever in zijne kostwinning en in het ophouden van zijn stand te helpen, en om voor zijn ouden dag en na zijn dood voor zijne begrafenis en den sterfboedel te zorgen; daartegenover staat het recht van den zorggever op een gedeelte van de erfenis van den zorgtrekker. Niet altijd echter is zijn aandeel even groot als van eigen kinderen van den zorgtrekker; in Rembokken bijv. is het regel, dat kinderen tweemaal zooveel krijgen als zorggevers, doch elders is de algemeene volksopvatting - ook door den landraad gevolgd - dat de zorggever in zijne rechten op den sterfboedel niet ten achter mag staan bij de eigen kinderen; bij gebreke van deze laatsten is de zorggever in allen gevalle overal de eenige erfgenaam.

De motieven van het "mengakoe anak» (Mal.) zijn velerlei. In de eerste plaats zoeken kinderlooze ouders of menschen, die nog jonge kinderen hebben en werkkrachten voor hun tuinarbeid behoeven, in hunne familie of daarbuiten geschikte personen, die zij als hun verzorger kunnen aannemen. Verder wordt veelal van deze instelling gebruik gemaakt door ouderparen die niets dan dochters hebben, of door ouden van dagen, die een verzorger noodig hebben, bijv. wanneer zij geen eigen kinderen hebben, dan wel, dat die kinderen gehuwd zijn en elders wonen, of, dat er verwijdering bestaat tusschen ouders en kinderen. Voorts is het een middel om stiefkinderen, die volgens de adat geen erfrecht hebben, een aandeel in de nalatenschap te verzekeren; ook komt het voor, dat twee ouderparen uit wederzijdsche toegenegenheid over en weer hunne kinderen "adopteeren»; of ook wel om den zorggever tot een huwelijk met een der eigen kinderen te brengen.

Uit de nadere beschrijving van dit zoo hoogst belangrijk Minahassisch rechtsinstituut is het den lezer reeds gebleken hoezeer het van de eigenlijke Indonesische adoptie (niet in den zin zooals door $\mathrm{Mr}$. van Ossenbruggen wordt bedoeld) verschilt. Een gewoon geadopteerd kind treedt uit zijne eigen familie om in de eigen familie van den adoptant opgenomen te worden; het wordt eenvoudig als een eigen kind van den adoptant beschouwd, zijne eigen ouders verliezen alle rechten op hem. Niet alzoo in de Minahassa. De verzorger, de zorggever blijft onder de ouderlijke macht van zijne eigen ouders; zij in de eerste plaats geven hem toestemming tot het huwelijk, al zal dan ook altijd de zorgtrekker in dezen een woordje mee te Dl. 81 . 
spreken hebben. In geen geval treedt de zorggever in de familie van zijn zorgtrekker; hij behoudt in den regel zijn familienaam, hoewel nu en dan van deze gewoonte wordt afgeweken, feitelijk om den zorgtrekker in het gevlei te komen; de betrekkingen tusschen zorggever en zijne (hare) familie blijven bestaan. Huwelijken tusschen een kind van den zorgtrekker en den zorggever; ja zelfs tusschen zorgtrekker en zorggever, hoewel zeer laakbaar, zijn niet verboden. Is elke vader zooals wij boven gezien hebben, verplicht zijne kinderen te onderhouden, als zorgtrekker is hij ten opzichte van zijn zorggever niet aan een dergelijken gebiedenden adatregel onderworpen, al zal hij dan toch vooral wanneer de zorggever bij hem inwoont, hetgeen volstrekt niet altijd gebeurt, gemeenlijk voor eene goede verzorging instaan. De zorggever heeft geen aanspraak op de nalatenschap van bloed- en aanverwanten van zijn zorgtrekker, tenzij bij het opmaken van de overeenkomst hem bijzondere voordeelen worden toegekend; twijfelachtig is het zelfs of de zorgtrekker eenig recht heeft op de nalatenschap van zijn zorggever.

Hoewel dus de zorggever eigenlijk geen lid is van de familie van den zorgtrekker, kan hij zich toch daarin eene belangrijke plaats veroveren en zich allerlei rechten aanmatigen, die hem niet toekomen. Dit geldt als een van de vele misbruiken der Minahassische "adoptie». Als eene andere ontaarding vermeldt mr. Alting het aannemen van personen als zorggever na overlijden van iemand om verzekerd te zijn van eene goede zorg voor de begrafenis, het z.g. soemapoet (Tb., afgeleid van sapoet $=$ omwikkelen, in dit geval omwikkelen van het lijk of de doodkist), dat vooral onder de Tomboeloe' veel voorkomt. Als vergoeding voor hunne hulp krijgen deze zorggevers, gewoonlijk simapoet genoemd, een aandeel (gewoonlijk minder dan het aandeel voor de eigen kinderen) der nalatenschap van den overledene, die hem niet eens persoonlijk heeft "geadopteerd ${ }^{1}{ }^{1}$ ). Het is niet onmogelijk, dat het simapoet-contract, zooals door prof. van Vollenhoven en $\mathrm{mr}$. van Ossenbruggen ${ }^{2}$ ) wordt verondersteld, van ouds eene gewone adatsinzetting is

1) Zie Carpentier Alting I 1e stuk blz. 112-113.

2) Zie van Vollenhoven t.a.p. een inlegvel behoorende bij de beschrijving van het Minahassisch adatrecht en Wilken II blz. 406 noot 43, voorzien van eene aanteekening van $\mathrm{mr}$. van Ossenbruggen. 
geweest en dus geen ingeslopen misbruik kan genoemd worden. Onder de Tomboeloe' moet het toch een oude gewoonte geweest zijn, dat degene, die aan de begrafeniskosten heeft deelgenomen ook recht krijgt op een aandeel van de nalatenschap. Wellicht is het zelfs niet te gewaagd de veronderstelling te opperen, dat het "mékioki» uit het "soemapoet» is ontstaan.

Naar pastoor A. F. van Velsen, een uitnemend kenner van het Tomboeloe'sch mij mededeelde, is het in het district Tombariri (waar Tomboeloe' wonen' gewoonte om voor het aannemen van zorggevers nu nog algemeen soemapoet te zeggen.

Straks kom ik op dit punt terug.

Een algemeen misbruik was wel het «adopteeren, van hoofden om hen voor zich te winnen in geschillen, ook lieten zij zich vaak "adopteeren» door rijke personen in de negorij met het kennelijk doel om later uitgestrekte gronden te erven; verscheidene hoofden hebben zich op die wijze aanmerkelijk verrijkt. In 1890 heeft het Eุuropeesch bestuur tegen dit toenmaals hand over hand toenemend misbruik een streng verbod uitgevaardigd. ')

Evenmin in overeenstemming met de eigenlijke adat was de z.g. ouderaanvaarding, het door een aanstaanden zorggever aanbieden van hulp aan iemand, die bemiddeld was en van wien hij wat hoopte te erven. Geheel tot het verleden behoort dit uitgroeisel van de «adoptie» niet. Zoo werd mij verteld, dat in Tomohon het algemeene gewoonte is, dat iedereen, die maar wat op heeft met den een of anderen ouderen invloedrijken persoon in de negorij, dien komt vragen hem als "sangkoem» te willen beschouwen. Deze sangkoem's krijgen dan niets dan een klein geschenk maar hebben de verplichting "hun vader» bij de tuinwerkzaamheden of bij feesten en begrafenissen te helpen. Een bepaald recht op de nalatenschap wordt hun lang niet altijd verzekerd. Merkwaardig is het $\mathrm{maki-ina}=$ het tot moeder aannemen van een jongen man ten opzichte van een jong meisje. Van alles moet de jongen dan voor zijn "moeder» doen, en als wederdienst wascht zij zijne kleeren of speelt zij als postillon d'amour, enz. Vaak ontstaat echter al heel gauw tusschen beiden eene verloving of eene ongeocrloofde verhouding.

Van een verdwijnen der Minahassische "adoptie» is nog geen sprake. De heer Wawo Runtu wees daar dan ook in den Volksraad

1) Zie Wilken II blz. 359-360. 
op, en het is jammer, dat de Directeur van Justitie in antwoord daarop mededeelde, dat in het nieuwe Burgerlijke Wetboek voor alle bevolkingsgroepen waarschijnlijk wat de adoptie betreft verwezen zou worden naar het plaatselijk gebruik ${ }^{1}$ ). Beter was het voorstel van Mr. Carpentier Alting om dat "plaatselijk gebruik » zoodanig te codificeeren, dat daar mede meer rechtszekerheid zou bereikt worden ${ }^{2}$ ). Dat de adat zelve zelfs door invloedrijke personen niet in goeden zin veranderd kan worden, blijkt wel voldoende uit de geringe resultaten, die wijlen het districtshoofd N. E. Mogot (Langoan) bereikt heeft met zijne nog wel in overeenstemming met het volk aangebrachte verbeteringen in de "adoptie». De door hem in eene "soerat bersamaan» met de hoofden, negorijbestuursleden en ingezetenen van Langoan (zie Adatrechtbundel III blz. 183 e.v.), opgestelde bepalingen, die o.a. eenige wijzigingen van het verzorgingscontract beoogden worden nu slecht of in het geheel niet nagekomen.

Eene echte adoptie wordt in de Minahassa alleen aangetroffen in het in vele opzichten zoo merkwaardige Tonsawang. Het heet tinangkèng akanombal, hetgeen beteekent "opgeheven uit de pinangschors" ${ }^{3}$ ) omdat het geadopteerde kind in zulk een schors naar het huis van den adoptant (it o e makèng a kanombal) werd gebracht. Deze adopteert immers alleen pasgeboren kinderen; het motief dezer adoptie behoeft niet te zijn kinderloosheid van den adoptant, er zijn er die reeds kinderen bezitten en toch nog adopteeren. De geadopteerde wordt geheel in het gezin en de familie van de adoptiefouders opgenomen, de adoptivus verandert vaak van familienaam. Echter schijnt de band met de vleeschelijke ouders niet geheel verbroken te worden, aangezien de geadopteerde behalve erfrecht ten aanzien van adoptant ook recht heeft op de nalatenschap van zijne eigen ouders. Deze adoptie kan onmogelijk opgeheven worden; zij werd - het $\mathrm{t}$ in a n $\mathrm{g} \mathrm{k}$ èn $\mathrm{g}$ a $\mathrm{k} \mathrm{a} \mathrm{n} \mathrm{o} \mathrm{mb} \mathrm{b}$ komt nog zeer zelden voor wel eens toegepast bij huwelijken tusschen weduwnaar en weduwe. Zooals wij boven gezien hebben was de man bij aangaan van dergelijke huwelijken verplicht de weduwe een geschenk ( $\mathrm{d}$ o c ho) te geven. Had die weduwe nu nog een kindje uit haar vorig

1) Zie Handelingen t.a.p. blz. 263-267.

2) Zie zijn ontwerp in deel I blz. 85 e. v. en eerste deel derde stuk blz. 177 .

3) En niet: iets van eene plaats nemen en naar eene andere plaats overbrengen, gelijk Carpentier Alting I. 1e stuk blz. 107 noot schrijft. 
huwelijk en werd dat door den weduwnaar geadopteerd, dan behoefde hij geen docho te geven.

Onder de Ponosakanners is het nog gewoonte alleen kleine kinderen aan te nemen (hosonintoentoel), die kinderen worden opgenomen in de familie van de adoptiefouders, zij veranderen ook van achternaam en krijgen de toestemming tot het huwelijk van hunne adoptiefouders.

Naast de adoptie komt in Tonsawang toch ook voor het verzorgingscontract, dat daar $\mathrm{mang}$ o e a heet en meer op fosterage lijkt dan het bovenbeschreven verzorgingscontract onder de andere Minahassische stammen. De zorggever (pinangoean) wordt meestal toch in het gezin van den zorgtrekker (nimangoea) opgenomen, maar heeft geen erfrecht ten opzichte van de nalatenschap van den zorgtrekker; wel krijgt hij echter gewoonlijk eene belooning, hetzij bij zijn huwelijk of bij den döod van den zorgtrekker.

Men zọu uit het bestaan dezer beide instellingen onder de Tonsini kunnen afleiden, dat wellicht eertijds onder de andere Minahassische stammen adoptie en verzorgingscontract naast elkander voorkwamen, doch dat zij in den loop der tijden in elkander gevloeid zijn. Een andere hypothese omtrent het ontstaan van het eigenaardige "mekioki" vermeldde ik reeds, n.l. de veronderstelling, dat het in het soemapoet zijn oorsprong zou hebben. Eertijds toch waren begrafenissen met de daaraan verbonden doodenmalen zeer kostbaar, misschien te kostbaar voor een niet al te bemiddeld persoon, hulp van familieleden was dan onontbeerlijk. Als vergoeding voor hun steun kregen zij dan een deel van de nalatenschap. Dat was het soemapoet. Langzamerhand ging men er toe over om reeds bij zijn leven iemand aan te nemen, die later voor de begrafenis had te zorgen, tegen belooning van een deel van zijne nalatenschap. In een volgend stadium werd iemand aangenomen tegen eenzelfde vergoeding, doch met het doel niet alleen om van eene goede begrafenis verzekerd te zijn, maar ook om al dadelijk, dus nog gedurende het leven, een zorggever te hebben. Eene dergelijke ontwikkeling van het «mekioki» zou men zich alleen kunnen denken onder de Tomboeloe', aangezien bij hen het soemapoet regel was en nu nog steeds in zwang is.

Volgens Mr. Carpentier Alting ${ }^{1}$ ) zou de «adoptie» ontstaan zijn

1) Eerste deel eerste stuk blz, 125-127. 
in de periode, dat het moederrecht overging in het patriarchaat. De vrouw, vroeger eene medearbeidster in het huis harer ouders, trok thans bij haar man in, zoodat de eene familie een arbeidskracht won ten koste der andere. De opengevallen plaats werd dan door "adoptie» aangevuld. Wilken ${ }^{1}$ ) zoekt de oorsprong van deze eigenaardige instelling in den tijd toen de vrouw nog niet aan een bepaalden man gebonden was en het vaderschap van een kind nog geheel onzeker was. Mr. S. R. Steinmetz meent, dat de Minahassische "adoptie" oorspronkelijk eene uiting van fosterage is geweest. Deze gewoonte zou dan ontstaan zijn in den tijd, dat het zich ontwikkelend moederrecht in strijd kwam met eene overoude "Vatergewalt, dan wel in dien van den overgang van het moederrecht in het patriarchaat. \&In beide gevallen tracht de moederfamilie de kinderen der vrouw aan den man te onthouden en te onttrekken." ${ }^{2}$ ) Dit onthouden en onttrekken bereikt men alleen door het kind bij een der familieleden te doen opvoeden.

Beide bovengenoemde meeningen van Wilken en Steinmetz zijn door mr. Alting bestreden. Het is $\mathrm{m}$. i. hier niet de plaats zijne verschillende argumenten te vermelden; wie daarin belangstelt zij verwezen naar het meergenoemd rapport deel II le stuk blz. 119-127.

Mogelijk is wel onder fosterage te rekenen de gewoonte van ouders, om hun kind bij een ander ouderpaar in den kost te doen, omdat zij vorige kinderen voortdurend verloren hebben; men verwachtte dus van zulk een overgang een magischen invloed op het kind, dat voor het lot van zijne overleden broertjes en zusjes bewaard zou blijven. Vroeger trachtte men dit doel te bereiken door het kind quasi te vondeling te leggen (itéa Tb., ikéa Tt., of iséro $\mathrm{Td}$.), thans echter wordt het kind eenvoudig aan andere ouders ter verpleging gegeven. Het kind mag dan zijne eigen ouders niet meer vader of moeder, maar wel zus of broer noemen. Deze gewoonte noemt men in het $\mathrm{Tt}$. is a'ket van $s_{s} a^{\prime} k e t=$ iets schuiven op een ander. In Tonsea bestaat de gewoonte om kinderen op te nemen, die men met succes doch met veel moeite van een langdurige ziekte heeft genezen. Deze kinderen noemt men rinti' oen sedep (sedep is een bekend inheemsch geneesmiddel tegen kinderziekten).

1) Deel II blz. 375-376.

3) T.a.p. blz. 1093 . 
Deze en andere wijzen van opneming van pleegkinderen ${ }^{1}$ ) hebben geen rechtsgevolgen, doch het komt wel voor, dat een pleegkind geadopteerd wordt.

\section{Animistische bestrijding van ziekten.}

Het is mij niet mogelijk in dit reeds groote hoofdstuk van «Zeden en gewoonten» de volksgeneeskunde in haar geheel te beschrijven, wel echter om enkele wijzen van genezing door middel van magie mede te deelen.

De primitieve mensch meent, dat ziekten een gevolg zijn van het verdwijnen van eene zekere kracht uit het menschelijk lichaam. Het is dan zaak het verdwenene terug te winnen. Alleen de medicijnmeester - vroeger de priester (walian), thans de maoemdam ( $\mathrm{Tt}$.), - is daartoe in staat. Hij begint den zieke te ondervragen waar hij gedurende de laatste dagen heeft vertoefd; mogelijk heeft hij bij bronnen of in bosschen of badplaatsen, alle verblijfplaatsen van booze geesten, eene wijle vertoefd. Wellicht heeft de zieke taboe-voorschriften overtreden, bijv. hij is, niettegenstaande onheilspellende vogelgeluiden of het zien van een zwarte slang toch iets begonnen, zoodat de geesten van voorouders of kwaadaardige geesten zich op hem hebben gewroken.

Is het bekend waar het verdwenene gevonden zou kunnen worden, dan gaat de medicijnmeester naar die plaats toe, spreidt daar op den grond een lap katoen voor zich uit en tracht de ziel, den geest of hoe men ook het verdwenene mag noemen, terug te lokken door haar aan te roepen en offers uit te stallen, zooals gekookte rijst, gekookte eieren, kip, sirih en pinang, alles in kleine hoeveelheden of in kleinen vorm, misschien wel, omdat men gelooft, dat de ziel (zoo noem ik gemakshalve de uit het zieke lichaam verdwenen kracht) de gedaante heeft van een homunculus (een klein menschje ${ }^{2}$ ). Heeft de ziel gehoor gegeven aan de lokstem van den medicijnmeester en zit zij naar alle waarschijnlijkheid in de uitgespreide lap, dan wordt

1) Bekend zelfs onder de Europeanen is de instelling van het "anak piara", (Mal.), het opnemen van pleegkinderen, die feitelijk bediendenwerk moeten verrichten voor hunne verzorgers, die hunne kleeding en voeding hebben te bekostigen. Zie Adatreehtbundel IX blz. 51-52.

2) Bij de Toradja's heet het "verdwenene" tan oana = menschje en bij de Tontèmboan heet het katotow an, dat dezelfde beteekenis heeft. Zie Alb. C. Kruyt. Het animisme in den Indischen Archipel bly. 12-13. 66-68. 
deze laatste vlug opgevouwen en medegenomen. Is de geneesmeester aan de deur van het huis van den zieke gekomen, dan moet iemand op zijn kloppen vragen: "Is N. N. (de naam van den zieke) daar?» Natuurlijk is het antwoord bevestigend, de geneeskundige treedt binnen en snelt naar het ziekbed waar de doek boven het hoofd van den kranke wordt opengevouwen. Herstelt de zieke dan nog niet, dan is dit een teeken dat de ziel weer uit den doek is ontsnapt. Men noemt deze handeling, die nog steeds wordt toegepast, ma nèmpè (Tb., Td.), manga pei (Rat.) ${ }^{1}$ ).

Een andere wijze van genezen geschiedt door aan het hoofdhaar te trekken. Vandaar dat men in Tonsawang de doekoen lotoean $=$ de haartrekker noemt. Gewoonlijk geschiedt dit lotoe op de volgende wijze: eene vrouw buigt zich over den zieke heen, daarachter staat eene tweede vrouw, die eenige haren van de andere vrouw om haar vinger wikkelt en dan telkens vraagt of de ziekte veroorzaakt is door booze geesten, door vergif enz.; bij elke vraag wordt dan aan het haar getrokken en scherp geluisterd of het geluid geeft, zoo ja, dan weet de lotoean waaraan de ziekte te wijten is en hoe die genezen moet worden. Een dergelijk gebruik kwam naar men mij mededeelde, ook wel in Tonsea voor.

Het is algemeen bekend, dat aan het haar eene bijzondere magische kracht wordt toegeschreven. Zoo is het in de Minahassa bekend, dat wanneer een kind valt of zich kneust, de moeder of eene andere toesnellende vrouw haar eigen haar los maakt en dit tegen de pijnlijke plek drukt of het haar daarover uitslaat. ${ }^{2}$ )

Het ontbreekt niet aan andere magische geneeswijzen. Zoo bijv. het z.g. mala p. Men strijkt met een blad over het lichaam, prevelt eenige formules en verwijdert dan plotseling op handige wijze een van tevoren verstopt voorwerp - door een booze geest in het lichaam gebracht - daaruit.

Van naaktloopen als afweermiddel tegen ziekten werden mij slechts enkele gevallen genoemd.

Bij epidemieën was het de gewoonte de negorijen van booze geesten te reinigen; nog in 1918 gedurende de influenza-epidemie geschiedde dit in de negorij Toemaloentoeng (Tonsea), toen

1) Zie Graafland I blz. 475 e.v.

2) Zie ook Kruyt t.a.p. blz. 26 e.v. 
het geheele dorp in optocht naar de z.g. paséla d.i. de plaats waar voorheen de groote godsdienstige feesten plaats hadden, optrok, om die schoon te maken en met veel gerucht de booze geesten te verdrijven. Het betrokken dorpshoofd heeft er later veel van moeten hooren! In Tonsawang werd in dienzelfden tijd in de negorij door alle inwoners tegelijk op planken en balken geslagen om zoo de geesten te verdrijven. In Ponosakan is bekend het kalken van een kruisteeken op deuren en vensters tegen afwering van ziektewekkende invloeden. Ook roept men daar bij een zieke nog wel eens eene vrouw die met veel gerucht al dansende de "verdwenen geest met speer of hakmes moet lokken. Een andere gewoonte in dit Mohammedaansche land, om eene ziekte te verdrijven is het z.g. tawap (van het Arabische ța $\mathbf{w} \overline{\mathrm{f}}$, de bekende verplichte rondgang om de Ka'bah in Mekka) d.w.z. een rondgang door het dorp van oude en jonge mannen, die allerlei Arabische formules en gebeden opdreunen. Op ieder der vier hoeken van de negorij roepen zij dan de bang of a dan (de gewone oproep tot de "gebedsuren») uit. Drie of zeven dagen daarna worden de graven schoongemaakt en gaat men in de moskee of in een bepaald huis de "doa tolak bala' (Mal.) d.i. het gebed, dat het onheil moet afwenden, bidden.

Ziekmakende geesten heeten over het algemeen sakit. Vreeselijk is het door hen bezeten te zijn. Het eenige middel is dan den patiënt te berooken, gewenscht is het dan brandmateriaal te gebruiken, dat stinkt of eene scherpe lucht geeft bijv. Spaansche peper, hars, vodden, stukken van eene oude pajong, zwavel, enz. Onder de booze geesten is vooral bekend de lolok of loemilinter ( $\mathrm{Tt}$.) of maririnter (Tb.), een boschgeest, die er uitziet als een volwassen mensch, doch niet grooter is dan een kind, en lang haar draagt, dat over den grond sleept: Als men in het bosch door dien geest bezeten wordt, dan verdraaien de oogen, men verdwaalt en wordt gek. Er rest dan nog één middel: de oogen met Spaansche peper inwrijven. ${ }^{1}$ )

Booze geesten zijn ook wel eens geincarneerd in dieren. Zoo veroorzaakte tusschen 1883 en 1885 eene zwarte kat in de negorij Soekoer voortdurend ziekten, zoodat het dorp verplaatst

1) Zie Tontemboansche teksten vertaling blz. 114 . 
moest worden. Ik besprak reeds het geloof in den vampier, die zich in eene vleermuis kan incarneeren. Ook hoor ik, dat er verhalen bestaan van een op vier pooten loopende songko; waarschijnlijk is dit het over de geheele wereld verbreide geloof in den weerwolf.

De geesten van verwante afgestorvenen de moe'koer (Tt.) kunnen het den levenden ook lastig maken; zij kunnen zieken en zelfs pasgestorvenen, die niet behoorlijk worden bewaakt, wegrooven. Zieken en dooden worden ook nooit een oogenblik alleen gelaten. Een middel om zich de moe'koer's van het lijf te houden is: kort na de begrafenis water, vermengd met wat aarde van het graf van den overledene, of aftreksel van houtspaanders der doodkist, drinken.

Lijkbezorging, Rouwgebruiken en Erfrecht.

Vroeger placht men om het sterfbed, zelfs reeds aan het ziekbed een "heidensch, lawaai te maken ${ }^{1}$ ). Wel bestaat nog overal het ma'ajap (Tt.) of ma'amè (Tb.) en in het Tons. monabi d.w.z. het op weeklagenden toon uitroepen van de vele deugden van $\operatorname{de}(n)$ overledene door allen (vooral vrouwen), die het sterfhuis bezoeken ${ }^{2}$ ). Gehuurde klaagvrouwen, die men elders wel aantreft, zijn hier onbekend. Wel werden vroeger walian's of tona'a's gehuurd, die bij het lijk op klagenden toon de geschiedenis der voorgeslachten van den overledene moesten vertellen.

Zoodra de dood geconstateerd is, wordt het lijk gereinigd, daarna wordt het in een mooi pak gestoken, of in witte doodskleederen. Aan den doode worden verder allerlei voorwerpen, spijzen en dranken medegegeven, opdat de ziel in het hiernamaals over niets te klagen zal hebben. In de kist van een kind legt men gewoonlijk alle kleederen van $\operatorname{de}(n)$ overledene, de ouders worden dan daardoor niet meer aan het kind herinnerd zegt men.

1) Zie omtrent oude gewoonten lijkbezorging en rouwgebruiken betreffende Graafland I blz. 477 e.v. en N. Ph. Wilken.

2) Zie omtrent dit weenen, dat volgens ethnologen niet altijd eene uiting van droefheid, doch meer een afweermiddel tegen booze geesten is, Wilken I blz. 173 noot 1.

Zie ook Mr. F. D. E. van Ossenbruggen. Het primitief denken enz. t.a.p. blz. 179 e.v. 
In de negorij wordt het overlijden dikwijls door het luiden van de kerkklok bekend gemaakt, de tuinarbeid wordt dan gestaakt, een ieder keert naar de negorij terug om te helpen. Het maken van de kist, het dragen van de baar en het graven van de groeve toch is negorijzaak. Daarom moet dan ook het dorpshoofd spoedig alles regelen.

Meestal behoeven echter de negorijgenooten geen doodkist te maken, de overledene heeft er vaak reeds bij zijn leven voor gezorgd. Men ziet dan ook dikwijls onder het huis meerdere kisten liggen. In dat geval zegt het bijgeloof, dat men de kist niet "doodkist», maar bijv. "de plaats waar borden bewaard worden» of "de plaats waar kleederen in bewaard worden" noemt. Zooals ik immers zoo juist vertelde, geeft men den doode gewoonlijk kleederen of - vroeger meer dan thans - borden mee, vandaar de typische omschrijving. Zoolang het lijk in het huis is wordt het ook des nachts door een kring van familieleden bewaakt. Om elkander dan wakker te houden en af te leiden wordt er gedurende deze doodenwake geschertst en gelachen, gekaart, of het een of ander Hollandsch spelletje gespeeld, ja dikwijls hoort men er dubbelzinnige, piquante moppen vertellen.

Vóórdat de baar het huis uitgedragen wordt, spreekt de inlandsche godsdienstleeraar of een lid van den kerkeraad in een toespraak en in een gebed den zegen uit en wordt er door de aanwezigen een psalm gezongen. Daarop wordt de kist opgetild en door de dragers, die in lange zwarte baadjes gekleed zijn, naar het kerkhof gebracht; er zijn ook gemeenten die een lijkwagen bezitten. Oude gebruiken, zooals het driemaal rond het huis dragen van het lijk of het uitdragen van de baar door een gat in den houten vloer in den wand, in Tonsawang vroeger algemeen, zijn thans verdwenen. ${ }^{1}$ ) De begrafenisstoet wordt geopend door een der bovengenoemde godsdienstvoorgangers, daarachter volgt de baar, het naaste familielid van den overledene loopt achter de kist, terwijl de overige begrafenisgangers zich er achter aansluiten. Het strooien van padi voor den stoet uit komt nu nog wel voor, speciaal bij begrafenissen van dorpshoofden of oudjes. In Kawangko'an en Sonder is het gewoonte, dat gedurende de begrafenis psalmen gezongen worden door mannen en vrouwen zoowel jonge als oude, die naast de baar loopen, de vrouwen soms met

1) Zie N. Ph. Wilken. 
loshangende haren, hetgeen op een overoud gebruik wijst. Zelfs plachten mannen na de begrafenis met verwarde haren rond te loopen ${ }^{1}$ ). Is men bij het graf gekomen, dan wordt de kist neergelaten en gooit een ieder kluitjes aarde in de groeve. In Ratahan schijnt het gebruik te bestaan de aarde te bespuwen voordat $z$ ij in het graf geworpen wordt.

Nadat nog eenige toespraken zijn gehouden keeren allen terug naar het sterfhuis, waar alleen thee en sigaren worden aangeboden. Des avonds heeft voor familieleden en kennissen, die genoodzaakt zijn te overnachten een gastmaal plaats. Van de vele Heidensche doodenmalen zijn er niet vele overgebleven. Het meest bekende oude doodenmaal was de roemomang (Tb.), roemomah (Tons), koem ̌’k ̌s (Tt.), dat op den derden (soms ook den vijfden, zevenden of negenden) dag na de begrafenis gevierd werd, maar dat was niet het eenige. Zoo had men bijv. nog onder de Tomboeloe' het $\mathrm{m}$ a è rè $\mathrm{s}$-feest speciaal voor de mawasals, d. z. de priesters die den doode naar het schimmenrijk hebben te "geleiden»; het magoloong, een dans op het erf om het doodenhuis, na afloop waarvan de danseressen op het gereed gehouden maal moesten afvliegen; het «koeman oeng kan pasoe'" "het eten van warme rijst»; en ten slotte het mawoma, een feestje op den dag waarop de familie van den overledene naar den tuin gaat, om den geest van de(n) overledene eten te geven.

De doodenmalen waren berucht om hunne luidruchtigheid en om de groote inhaligheid van de priesters, die zich daardoor op onrechtmatige wijze wisten te verrijken ${ }^{2}$ ). Natuurlijk zijn zij nog niet verdwenen. Op den eersten Zondag na de begrafenis gaan alle familieleden in rouwgewaad vanuit de kerk naar het huis waar gegeten wordt; en verder is onder de Tomboeloe' en de Toulour nog gebruikelijk gebleven het bovengenoemd koema n oeng kan pasoe' onder den naam van koemawoes, dat door sommigen op den negenden dag, door anderen op

I) Zie Wilken III blz. 419-420. Wilken meent, dat deze gewoonte niets anders beduidt dan eene vermomming om zich niet voor de geesten herkenbaar te maken. Mr. F. D. E. v. Ossenbrnggen t.a.p. blz. 150 e, v. meent, dat oorspronkelijk naar de opvatting van den primitieven mensch van haar en vooral loshangend en ongekamd haar eene magische kracht moet uitgaan, die den drager of de draagster vrijwaart tegen de gevaarlijke magie, die van het lijk uitgaat.

2) Zie omtrent den oorsprong dier doodenmalen, eigenlijk niet anders dan doodenoffers, Wilken III blz. 102 en Kruyt t.a.p. blz. 321. 
den dag waarop de grafsteen gereed is, gevierd wordt. Het Christendom heeft de doodenmalen trachten te vervangen door het z.g. "tiga malam da ampat poeloeh hari (Mal.). Op den derden en veertigsten dag ${ }^{1}$ ) na het overlijden galmt men dan 's avonds in eene groote bijeenkomst in het sterfhuis psalmen tot middernacht. Vele kosten zijn hieraan niet verbonden, de familie heeft alleen voor koekjes en thee te zorgen. Dat overigens de andere bestaande doodenmalen nog kostbaar zijn, werd mij herhaaldelijk, vooral van het volk van Tonsea, medegedeeld. De familileden dragen die kosten, een ieder brengt zelf wat eten of geld mee. Die bijdrage, welke voor alle familiefeesten verplichtend is, heet in het Tt. roe'koep of soeroe' (Tb.). Men moet deze bijdragen niet verwarren met de bijdragen, die hier en daar iedere negorijgenoot moet betalen bij elk sterfgeval aan eene begrafenisvereeniging of het negorijbestuur, de z.g. soeroe' oem paté (Tb.), waarmee men de begrafeniskosten bestrijdt.

De grafsteen heeft niets specifiek-Minahassisch, hij is naar Europeesch model gemaakt, zelfs met Hollandsche, ja Fransche opschriften. Zoolang het grafmonument nog gemetseld wordt, worden er onder een tijdelijk afdak lampen gehangen, die des nachts branden. Dit afdak dient de ziel van den overledene tot verblijfplaats. Is het metselwerk gereed gekomen, dan wordt, zooals reeds is medegedeeld, wederom een eetmaal aangericht; ook kan dien dag wel samenvallen met den veertigsten dag na de begrafenis, die zooals wij gezien hebben door enkelen op Christelijke wijze gevierd wordt. - Nog vindt men in de Minahassa in grooten getale Heidensche graven, eigenaardige groote vierkante potten in trachiet uitgehouwen, die timboekar (Tt.) of waroega (Tb., Ts., Td.) worden genoemd. In Sawangan (Tonsea) heeft wijlen de majoor Pelankahu een groot aantal van deze graven die in de verschillende erven stonden naar eene verzamelplaats doen overbrengen. Deze wijze van begraven, in de ethnologie bekend onder den naam van Hockerbestattung, was alleen bekend onder de Tontèmboan, de Tomboeloe', de Tonsea, en Toulour. In streken waar men die graven niet gemakkelijk kon maken, werden alleen aanzienlijken daarin be-

1) Deze telling berust op Christelijken grondslag. Jezus toch stond op den derden dag na zijne kruisiging uit den doode op en voer op den veertigsten dag ten hemel. 
graven. Voor den minderen man had men dan òf houten ronde kisten, wa l on s ong (Tb.), t a m boelèlèng ( $\mathrm{Tt}$.) genaamd, of ook wel gewone kisten. De slaven echter werden gewoon in een mat gewikkeld met een omwindsel van platgeklopte bamboe, onder den grond begraven. De in de timboekar of tamboelèlèng begraven lijken werden in zittende houding met opgetrokken knieën tegen de kin in de open ruimte van den pot geplaatst ${ }^{1}$ ). Een zwaar deksel drukte het lijk nog dieper in den pot. Onder de Bantikkers, de Ratahanners, de bewoners van Ponosakan, en de Tonsini (Tonsawangers) bestond geen Hockerbestattung. Deze volken begroeven reeds van ouds hunne lijken in kisten. De laatsten hadden op de graven eigenaardige "zielehuisjes», als het ware kleine woningen waarvan de vorm voor de graven van mannen vrouwen en kinderen eenigszins verschilt; zij dienen tot verblijfplaats van de zielen der overleden personen ${ }^{2}$ ).

De achtergebleven weduwe of weduwnaar moest vroeger altijd door een andere weduwe of weduwnaar bewaakt worden en was aan bepaalde taboe-voorschriften onderworpen. Men mocht dan niet veel praten, niet lachen, men moest zich afzonderen en alleen met de bewakers eten, de bij het eten gebruikte voorwerpen mochten door niemand anders aangeraakt worden; verder mocht het eten niet in het sterfhuis bereid worden. Ook had men te zorgen het haar te verbergen en te bedekken met een bijzonder hoofddeksel, dat tindong of tindoeng (Wilken III blz. 419) heette. Van deze gewoonten zijn er nog vele in gebruik, vooral onder de Tomboeloe', de Tonsea, de Tontèmboan van Langoan, de Bantikkers, de Ratahanners en Tonsini. Anders echter is thans de rouwdracht, de tindoeng is niet meer in gebruik. Niet altijd was vroeger zwart de rouwkleur. Zoo moest onder de Tontèmboan eene kleindochter van een overledene een band van rood laken om het hoofd dragen, drie, vijf of zeven dagen lang ${ }^{3}$ ).

1) Zie over Hockerbestattung Richard Andree in Archiv für Anthropologie deel VI (1907), die meent, dat deze lijkbezorging gediend heeft om naar het volksgeloof de dooden te verhinderen uit hunne graven op te staan. Zie de aanteekeningen van mr. van Ossenbruggen in Wilken IV blz 105.

2) Zie over deze balosong's F. S. A. de Clereq, De grafteekenen der Alifoeroe in het district Tonsawang in het Tijdschrift voor Indische Taal-, Land- en Volkenkunde deel XXI blz. 102-103.

3) Zie Tontemboansch-Nederlandsch woordenboek onder het woord ñ gasi' dat behalve koppensnellen ook rouwen beteekent. 
Onder de Ponosakanners is nu nog wit de rouwkleur; men draagt die 40 tot 100 dagen. De zwarte kleur was niet anders dan een middel om zich voor de ziel van de(n) overledene te verbergen. Vandaar ook het gebruik, dat heden ten dage bijna niet meer voorkomt, het mahawoewoeringan, het elkander met houtskool zwart maken, wat onder zeer veel luidruchtigheid geschiedde na de begrafenis. Thans is zwart wel de algemeene rouwkleur. Vrouwen dragen een zwart baadje en sarong, dikwijls hebben zij eene zwarte sarong opgevouwen op het hoofd; zelfs de zakdoek, die zij voor haar mond moeten houden, wanneer zij huilen, behoort zwart te zijn. De mannen dragen zwarte, niet sluitende kabaja's. Ook zijn onder hen al in zwang de rouwbanden om de mouw, "stukkies» (Mal.) genoemd.

De oude rouwgebruiken gaan meer en meer verdwijnen. Zoo het roemow tana' (Tb.), het "verregaan». De weduwe of weduwnaar gaat dan de negorij uit, om elders familie en kennissen op te zoeken om aldus uit de gevaarlijke sfeer van het sterfhuis te zijn. Ook was het onder de Tomboeloe' een algemeen gebruik van de nabestaanden van $\operatorname{de}(n)$ overledene om naar een akker buiten de negorij te gaan en aldaar een klein gedeelte af te palen, dat beplant wordt met voedingsgewassen, en waar spijzen, dranken, borden en potten worden neergelegd, alles bestemd voor de(n) doode. Het is onder den Tontèmboan goed voor de nabestaanden om zoo spoedig mogelijk weer aan het werk te tijgen. Daarmede verwijdert men, volgens Schwarz ${ }^{1}$ ), den slechten invloed van de ziel van $\operatorname{de}(n)$ afgestorvene. Men noemt dit verrichten van arbeid la'loe. Ook was het gewoonte zijn verdriet zoo mogelijk met den stroom van het een of ander water te doen wegvloeien. Onder de Tomboeloe' moesten dan de vrouwelijke bloedverwanten met de weduwe of den weduwnaar, gesluierd, naar de algemeene badplaats om daar te baden. Een zeer typisch gebruik onder de Bantikkers (nu nog wel eens toegepast), om, naar de huidige opvatting, het verdriet van weduwen of weduwnaren weg te nemen is het maninta $=$ wegnemen van verdriet. Gedurende een huwelijksfeest worden twee vrouwen naar een huis gestuurd waar pas iemand is overleden; de eene vrouw draagt een groot bord bedekt met een soekoeboe (een doek met het patroon van de teekening der huid der z.g. patola-slang, een over de geheele

1) Zie Tontemboansch Nederlandsch woordenboek blz. 214. onder la'la. Zie ook onder loang (blz. 245). 
Minahassa zeer geliefd patroon), de andere een zwaard (bada'). Zij hebben niets anders te doen dan de weduwe of weduwnaar te bezoeken, en daarna weer terug te keeren naar het feest.

De nalatenschap (tela'oe Tt., toela'o e Tb., toeda'oe Ts., boendoe Bt., tingkoewa Rat. boho', Ponosakansch) bestaat uit roerende en onroerende goederen. Het is niet met beslistheid te zeggen of als erfboedei (niet te verwarren met nalatenschap) geldt de nalatenschap na aftrek van de kosten der begrafenis en van de schulden, zooals prof. van Vollenhoven (t. a. p. blz. 341) eerst meende, doch later naar aanleiding van mededeelingen van $\mathrm{mr}$. J. C. Kielstra ${ }^{1}$ ) betwijfelde. - Zijn de erfgenamen - zoo kan men de vraag ook stellen — verplicht het tekort van den sterfboedel bij te passen? De meeste mijner zegslieden beantwoordden die vraag bevestigend, de erfgenamen zouden zich schamen, als er schulden onbetaald zouden blijven. De heer E. W. J. Wawo-Runtu, oud-districtshoofd van Sonder, bevestigde dit, doch voegde er aan toe, dat eene bepaalde verplichting toch niet bestond. In Langoan was het antwoord pertinent ontkennend.

Bij de Bantikkers (Mandagie t.a. p. blz. 48) en ook bij de Ratahanners gaan de negatieve bezittingen over aan de erfgenamen.

Met deze vraag hangt samen de eigenaardige mededeeling van Dr. Buddingh ${ }^{2}$ ), dat in de Minahassa vroeger het lijk niet bijgezet mocht worden, vóórdat alle schulden betaald waren. In de litteratuur der oude Minahassische adat vindt men van zulk eene gewoonte niets gerept en mijne zegslieden wisten er niets van te vertellen, zij hadden er nooit iets van gehoord.

Het niet bestaan van zulk eene gewoonte (in Gorontalo en den Timorschen archipel wel bekend) sluit niet uit een aloude adat-regel, dat een ieder, die eene begrafenis heeft helpen bekostigen ook een deel van de erfenis krijgt, welke regel hoogstwaarschijnlijk ${ }^{3}$ ) vroeger gegolden heeft, en nu nog voortleeft

1) Zie Tijdschrift van het Binnenlandsch-Bestuur 1914 blz. 258-261. en zie het inlegvel in van Vollenhoven's werk, dat het artikel van den heer Kielstra bespreekt.

2) Dr. Buddingh. Reizen over Java, Madura, Makassar, Menado; enz. deel II blz. 52 en Wilken II blz. 406 noot 43 .

s) Zie Adatrechtbundel III blz. 28 onderaan en Wilken II blz. 406 noot 43. 
in het soemapoet bovenbeschreven. Men moest toch vroeger voor begrafenissen ontzachelijk veel kosten maken. Hulp van verwanten was dan welkom en kon niet anders beloond worden dan door het geven van een deel der nalatenschap.

De besprekingen omtrent de boedelverdeeling hadden vroeger plaats gedurende het roemomang en heeft nu nog bijv. onder de Bantikkers en v. z, m. b. ook in Rembokken, nog op het een of ander begrafenismaal (in Rembokken op de koemawoes) plaats. In allen gevalle maakt de familie alles onder elkander uit. Alleen wanneer er een scherp meeningsverschil is, wordt de tusschenkomst van het negorij- of districtsbestuur ingeroepen en als ook dat niet helpt, dan is eene uitspraak uitlokken van den landraad het laatste redmiddel. Hoewel de verdeeling van de poesaka aanleiding geeft tot veel gekrakeel, mag de geneigdheid daartoe zeer toegejuicht worden. Want het is in de Minahassa evenals elders in den Archipel gewoonte om een sterfboedel zoo lang mogelijk onverdeeld te houden; niet zelden is dit aan het familiehoofd, dat belang heeft bij het vergrooten van het door hem beheerd familiegoed, te wijten. Er zijn echter gevallen waarbij verdeeling niet dadelijk plaats kan hebben, zoo bijv. ingeval een man echtgenoote en minderjarige kinderen achterlaat. De door hem nagelaten erfenis (d. z. zijne goederen en de helft, soms twee derde deel van het gemeengewonnen goed), eigenlijk bestemd voor zijne kinderen, wordt dan tijdelijk beheerd door de weduwe. Doch ook wanneer één der kinderen meerderjarig is geworden en allen nog in het ouderlijk huis verblijf houden kan het nog wel eens gebeuren, dat het zijn aandeel nog niet opeischt, hetgeen de adat immers toestaat. $\mathrm{Z}_{\mathrm{ijn}}$ in een dergelijk geval beide ouders gestorven, dan treedt het oudste, meerderjarig kind op als beheerder der goederen van de onmondigen. Zoodra er echter geen minderjarigen in huis zijn dan verbiedt de adat, gelukkig, de kinderen, die het huis verlaten, niet deeling te vragen, doch hoe vaak verzetten zich dan andere belanghebbenden daartegen, zoodat dan weer de toevlucht genomen moet worden tot het dorps-, het districtsbestuur of den landraad!

Testamenten zijn in het adatrecht onbekend; toch komt het nog wel eens voor, dat men bij zijn leven de goederen reeds aan de erfgenamen toebedeelt en daarvan eene schriftelijke verklaring opmaakt. De erflater kan dergelijke boedelverdeelingen ])l. 81. 
alleen tot stand brengen met instemming van de familieleden ${ }^{\mathbf{1}}$ ). Het boven besproken verzorgingscontrakt ("adoptie») lijkt wel iets op een testament. ${ }^{2}$ ) Door middel van deze soort van overeenkomsten kan men personen, die volgens de adat geen erfrecht hebben, dat recht verleenen; men denke aan in huis opgenomen pleegkinderen, en vooral ook stiefkinderen.

Het is niet wel mogelijk hier eenige regelen omtrent de boedelverdeeling mede te deelen. De landraad houdt ten deze voornamelijk rekening met de voorschriften uit ons Burgerlijk Wetboek. ${ }^{3}$ )

\section{Grondbezit.}

Er bestaat over dit onderwerp een overstelpend aantal artikelen en gegevens ${ }^{4}$ ). Bij het raadplegen van de werken van Wilken en Riedel, de beide grondleggers van de thans ons bekende wetenschap der grondrechten in de Minahassa, zij de lezer vooraf gewaarschuwd tegen de onjuiste Hollandsche benamingen dier verschillende grondrechten. Door mij zal gevolgd worden de zeer juiste en duidelijke terminologie van prof. van Vollenhoven.

Zoo kent de Minahasser een bezitsrecht dat nogal afwijkt van het Europeesche eigendomsinstituut, omkneld als het Minahassisch grondbezit wordt door een vèrgaand beschikkingsrecht van het dorp, dat mag onteigenen zonder schadeloosstelling (Pandecten IV, A, plaatsen: 1019, 1021 en 1022), een beschikkingsrecht, dat echter gelukkig! gaat afslijten in verband met het sterk opkomend individualisme. In beginsel is nochtans de Overheid in enkele streken nog steeds bevoegd den Minahassischen grond-

1) Zie Adatrechtbundel IX blz. 160.

2) Van Vollenhoven t.a.p. blz. 341.

3) Zie ook Adatrechtbundel III blz. 13-30.

4) 1. Wilken II blz. 353-378 en blz. 381-387.

2. Adatrechtbundel III blz. 48-63; blz. 135-176; blz. 186-193.

3. Adatrechtbundel IX blz. $5-16 ; 146-149 ; 84-87$.

4. J. G. F. Riedel. Iets over het landbezit in de Minahasa. (Tijdschrift van Nijverheid en Landbouw in Nederl. Indië deel 14 blz. 1 e.v.).

5. Pandecten van het Adatrecht deel 1-IV.

6. $\mathrm{Mr}$. Carpentier-Alting t.a.p. I, 1e stuk blz. $65-70$.

7. Verzameling van vragen de regten betreffende welke in de Gouvernementslanden der residentie Menado op de onbebouwde gronden worden uitgeoefend. (1876).

8. Adatreohtbundel XVII.

9. Verder de verschillende werken en geschriften van prof. van Vollenhoven. 
bezitter, zij het tegen behoorlijke schadevergoeding, van zijn grond af te zetten, bijv. voor de uitbreiding der negorij. Verder is het individu niet altijd de eenige rechthebbende op den grond, doch behoort die soms tot een geheele familie ${ }^{1}$ ) of eene negorij of een district. Men onderscheidt daarom liever persoonlijk (pasini, kasasaan Tt.) van gemeenschappelijk (kalakéran, d.i. het verbasterde Tomboeloe'sch kalakerran, kakělian Tt., afgeleid van $l a k$ ěr, kěli = veel) bezits recht.

Familiegronden (tana' kalakěran oen taranak Tb.) treft men nog in groote uitgestrektheden over de geheele Minahassa aan. Daartoe heeft niet weinig medegewerkt de bovengenoemde adatregel, dat de door ieder familielid ontgonnen grond na zijn dood aan de familie toeviel. En nog is dit gebruik op verre na niet verdwenen. Weliswaar valt de individueel bezeten grond alleen aan de kinderen, maar dezen denken niet aan verdeeling, vooral niet wanneer het nagelaten stuk niet al te groot is. Zoo ontstaat dan grondbezit van eene familietak of -staak.

Het beheer over het familiegoed berust bij een familiehoofd of -oudste (kapala of toe'a oen tarana' Tb., Ts., Td., Tt. of iwotona'as Tons., magoedang tahan a Bt.). Als zoodanig fungeert niet altijd de oudste der familie, dikwijls ook de invloedrijkste, degene, die voor de buitenwereld een persoon van aanzien is, een hoofd of gewezen hoofd van district of dorp dus. Niet altijd wordt van de aanwijzing van zoo'n hoofd een schriftelijk «benoemingsbesluit» opgemaakt; in de practijk is dat nog wel eens noodzakelijk gebleken. Over welke familieleden de macht van het hoofd zich uitstrekt is niet altijd te zeggen, soms beperkt zij zich niet alleen tot de leden in opgaande of in afdalende linie, doch ook in de zijlinie, meermalen echter is de familie weer in staken gesplitst, die ieder weer een eigen oudste of hoofd hebben. Ook wel wordt het beheer overgelaten aan een raad van familietak-hoofden; in allen gevalle doet een wijs hoofd van eene groote familie verstandig jaarlijks vóórdat de gronden onder de leden verdeeld worden, de takoudsten te raadplegen en in overeenstemming met hun wil te handelen. De "těranak's» noemen zich meestal naar den stamvader, den zoogenaamden dotoe (Mal.); zoo spreekt men bijv. van

1) En niet alleen de grond doch andere goederen als huizen, vijvers, zelfs afgepaalde stukken in meren (rehen 'Td., pango' Langoansch, papa'an Tons., kala'oen of wonor Rat.). 
de tĕranak dotoe Elias Mogot in onderscheiding van de těranak dotoe Nicolaas Mogot.

Thans eene kleine afdwaling. Nu wij bezig zijn aan de familie als rechtsgemeenschap, mag niet onvermeld blijven, dat in de Minahassa overblijfsels bestaan van een vroeger z.g. classificatair verwantschapsstelsel d.w.z een stelsel waarbij verwanten, die op dezelfde generatielijn staan, dezelfde benaming hebben. In het Tomboeloe'sch bijv. heet de vader ama'; is de broeder van den vader getrouwd, dan wordt hij ook a ma' genoemd; is hij echter nog ongetrouwd dan wordt hij met ito' aangeroepen. Zoo spreekt men ook aan een oudere, dien men nog niet kent, ook wel gebruikt men dan het verhollandschte oom en voor eene vrouw moei. Ook wordt ito' gebruikt om een neef of nicht (ooms- of tanteskind) aan te roepen. De moeder noemt men in a', hare jongere zuster ina' koki' (kleine of jonge moeder) en hare oudere zuster ook in a'. Heeft men voor schoonouders eene benaming n.l. penigi'en (degenen die geeerd moeten worden) of pe mosan a n (wier namen uit te spreken voor den schoonzoon of schoondochter, posan, ongeoorloofd is; zelfs merkte ik onder de Bantikkers de gewoonte op, dat de schoonvader ook niet de naam van den schoonzoon of de schoondochter durft uit te spreken), de schoonzoon of -dochter wordt eenvoudig oki' genoemd. Merkwaardige overeenkomsten vindt men onder de Tontèmboan. Hier heet de vader a $\mathrm{mang}$ in den vocatief ama'. Zegt men se a mangami, dan worden daarmede bedoeld vader en zijne broeders en zusters. De moeder wordt in a' genoemd, hare oudere zuster eveneens, hare jongere zuster ra'a, hetgeen ook gebruikt wordt, indien men eerbiedwaardige vrouwen van eenigen leeftijd wil aanspreken. Ra'a wordt ook de stiefmoeder door de stiefdochter genoemd, als de verhouding niet hartelijk genoeg is om inang te zeggen ${ }^{\mathbf{1}}$ ). Een overblijfsel van het genoemd verwantschapsstelsel is ook het zeggen van vader tegen oudere menschen (denk aan het "pa" van den Javaan), hetgeen onder de Tontèmboan blijkbaar voorkomt. Men spreekt dan van si a mangéra waarmede men aanduidt een man wiens naam men niet wil of kan noemen ${ }^{2}$ ).

Ten slotte nog een enkel overeenkomstig voorbeeld onder de Bantikkers. Den vader noemt men a ma', de moeder ma', de

1) Z:e Tontemboansche teksten. Aanteekeningen blz. 36 .

2) Zie Tontemboansch-Nederlandsch woordenboek. 
oom heet nu ama'kadio, de tante ma'kadio. Kadio beteekent «klein» ${ }^{1}$ ). Oom en tante zijn dus «kleine», d.i. "oneigenlijke» vader en moeder.

We keeren thans terug tot de familie-hoofden, ook wel eens in het Mal. "pengatoer» genoemd. Hunne taak bestaat voornamelijk in het verdeelen van den familiegrond. De leden of staken toch hebben geen gewoon Inlandsch bezits-, doch slechts gebruiksrecht op dien grond. Worden daarop alleen eenjarige gewassen geplant, dan moet de pengatoer elk jaar opnieuw de familieleden aanwijzen, die den grond mogen beplanten. In de meerdistricten is het grondbezit reeds zoo beperkt en is de dichtheid der bevolking zoo groot, dat het voorkomt, dat een familielid of -tak slechts eens in zijn leven een aandeel in den familiegrond gebruikt. Feitelijk mochten op familiegrond geen veeljarige gewassen geplant worden, doch gelukkig was en is de adat een levend iets, dat in dit opzicht met zijn tijd meeging; sedert de klappercultuur hier ingang vond, werden de familiegronden ook met de zoo winstgevende palmen beplant. Nu moest aan bepaalde familieleden of -staken een permanent gebruiksrecht toegestaan worden, dat slechts in enkele opzichten van het Inlandsch bezitsrecht afwijkt. In de eerste plaats verbiedt het vervreemding aan niet familieleden en in de tweede plaats moet bij eventueele verdeeling van familiegrond een bestendig gebruikt aandeel ook ingebracht worden, hoewel de gebruiker, indien de verdeeling tot stand komt, meestal het voorrecht heeft bezitter van den grond te worden.

Het familiebezit is een rem voor allen vooruitgang en eene oorzaak van veel getwist en geringe rechtszekerheid. De door resident E. J. Jellesma in 1895 ingestelde commissie van aanzienlijke Inlanders, die een rapport over het toenmalig adatrecht moesten uitbrengen, zag dat in 1896 reeds in en stelde voor om hierin verbetering te brengen, voornamelijk door:

$1^{\circ}$. het opmeten van alle gronden en het opnemen daarvan in een register;

$2^{\circ}$. voor te schrijven, dat niemand genoodzaakt is in een onverdeelden boedel te blijven; ${ }^{2}$ )

1) Zie P. A. Mandagie t.a.p. blz. 43 waar men ook andere verwantschapsbenamingen vindt.

2) Overgenomen uit artikel 1066 van het Burgerlijk Wetboek. 
$3^{\circ}$. het procedeeren te vereenvoudigen ${ }^{1}$ ).

Het nieuwe Agrarisch Reglement voor het gewest Menado ${ }^{2}$ ) in 1918 ingevoerd, heeft, helaas, nog steeds niet aan dezen wensch van volksvertegenwoordigers zelve toch, voldaan. Dat Reglement schrijft voor, dat verdeeling van familiebezit van gronden met toestemming van het hoofd van plaatselijk bestuur (meestal de controleur) kan geschieden mits o. a. alle "naar de ter plaatse geldende rechtsbegrippen tot het nemen eener beslissing in familiezaken " bevoegd zijnde personen de ontworpen wijze van verdeeling goedkeuren, dat wil dus zeggen, dat nagenoeg alle meerderjarige familieleden roor verdeeling moeten zijn. Maar een ieder, die de practijk kent, weet hoe weinig eensgezindheid er onder bloedverwanten bestaat, hoe vaak juist eene koppige minderheid alleen uit wrok eene domme obstructie voert, of, dat juist het familiehoofd met baatzuchtige bedoelingen den goeden wil van andere familieleden tegengaat. Wat helpt dan nog alle overredingskracht van den controleur, die, naar het Reglement voorschrijft, moet aangewend worden om den onwillige tot ander inzicht te brengen. - Een ander bezwaar is, dat veelal ook enkele verwanten niet meer in de Minahassa vertoeven en dus zeer moeilijk gehoord kunnen worden. $\mathrm{Zij}$ zijn het veelal, die tegen verdeeling zijn, omdat zij bevreesd zijn, dat hunne belangen niet voldoende behartigd worden.

Gelukkig echter komt nog wel verdeeling uit eigen vrijen wil van alle belanghebbenden tot stand. Eene verdeeling onder alle meerderjarige familieleden is dit gewoonlijk niet, wel echter eene verdeeling onder de familiestaken. - Bij zulk eene verdeeling werd gewoonlijk een stuk grond onverdeeld gelaten, men noemde dat tana' pasoesoengkoelan Tb., tana' wawakes oen taranak Tt. en tana' eti Ts.; het is, 7.0oals het Tontèmboansch woord ook aanduidt een bindmiddel voor de familie. Eveneens was en is het nog gewoonte om het familiehoofd bij zulk eene verdeeling een extra-aandeel toe te bedeelen. Handhaving van dezen adatregel zou nog menig hoofd eerder tot verdeeling brengen.

Niet alleen op deze wijze is het individualisme ontstaan, ook door eigen ontginning. Ontgonnen grond blijft steeds in het Inlandsch bezit van den ontginner, dat is een adatsvoorschrift

8) Zie Adatrechtbundel III blz. 10 e.v. en blz. 62 e.v.

1) Zie Staatsblad $1918 n^{\circ} 80$. 
waarover alle Minahassische adatkenners het eens zijn. Zoo ziet men overal in de Minahassa groote uitgestrektheden halfverwilderde gronden '), die, hoewel reeds jaren lang verlaten, toch nog bezit zijn van personen of rechtsgemeenschappen, en maar niet ontgonnen worden, omdat er nog gronden in overvloed bestaan of omdat zij nog niet voldoende begroeid zijn. Ook legt men liefst zijne tuinen aan in één aaneengesloten complex om gezamenlijk beter de wildezwijnen-plaag tegen te gaan. Heeft men in zoo'n complex geen gronden, dan leent of huurt men die van anderen. De aanwijzing van de buurt waar de akkers aangelegd zullen worden geschiedde vroeger door districts- of dorpshoofd, thans meestal door den laatstgenoemde in overeenstemming met de oudsten uit de negorij ${ }^{2}$ ).

Een éénmaal krachtens ontginning gevestigd bezitsrecht wordt zelden - men kan beter zeggen : nooit - prijsgegeven; evenmin is tot-den-staat-van-woestheid-terugkeerende grond als prijsgegeven te beschouwen. Elders schijnt dat wel het geval te zijn, zoo bijv. in Atjeh, in de afdeeling Lematang Oeloe van Zuid-Sumatra, in de Doesoen-landen van Z.-O. Borneo, Zuid-Celebes (in districten waar bepaald gebrek aan tuingrond is) ${ }^{3}$ ). Bevreemdend is het daarom, dat het Agrarisch Reglement eene tijdelijke ingebruikneming van grond ingevoerd heeft, voor de Minahassa eene nieuwigheid, die zeer waarschijnlijk weinig of geen toepassing zal vinden. Mogelijk echter wel in het volgend geval. De tijdelijk in de kuststreken vertoevende vreemde Inlanders zooals de Sangireezen, Gorontaleezen, Badjo's e.a. verkregen vroeger het recht in het territoir van een district te ontginnen; verlieten zij de streek weer voorgoed, dan verviel hun grond aan de gemeenschap, vroeger het district, thans het land. Een dergelijk verleend

1) Deze gronden hebben verschillende benamingen (Zie Adatrechtbundel III blz. 151-153 en blz. 164), doch over het algemeen duidt men ze aan, door het woord djoerame.

2) De wetgever van het Agrarisch Reglement meent hieruit te moeten afleiden dat eene tijdelijke ingebruikneming van domeingrond in de Minahassische adat thuis hoort. (Zie de toelichting van het Reglement blz. 26). Men heeft hier echter te doen met ingebruikneming van gronden, waarop het Inlandsch bezitsrecht rust.

3) Zie Pandecten van het Adatrecht deel II plaats 221, 227, 236 en 242. Merkwaardig is, dat het meergenoemd Agrarisch Reglement, dat eene adatscodificatie wil zijn, ook een duurzaam bezit van slechts voor korten tijd ontgonnen grond ook voor de Minahassa niet erkent (zie artikel 1 sub. 6 en Toelichting blz. 21). 
ge notrecht, zooals prof. van Vollenhoven (t.a.p. blz. 347) dat tijdelijk bezitsrecht heeft genoemd, is te vergelijken met de tijdelijke ingebruikneming van het nieuwe Agrarisch Reglement.

Het individueele bezit (pasini) is een schier onbeperkt recht om over den grond te beschikken. De drager van dat recht kan zijn grond verkoopen en verpanden aan wien hij wil; ook is hij gerechtigd zijn bouwveld in gebruik te geven aan anderen; een rijke grondbezitter makt van dat recht gewoonlijk gebruik, om zijne gronden tijdelijk af te staan aan gehuwde kinderen.

De verkoop en verpanding van gronden zijn eveneens in het Agrarisch Reglement nader geregeld; ook ten deze was codificatie van de adat kebisa ä n noodzakelijk geworden, in het bijzonder voor de meerdistricten en Tonsawang. Is daar het tijdstip van de bewerking of den oogst aangebroken, dan regent het zaken. A bewerkt zonder blikken of blozen eene sawah waarvan $B$ zegt dat die van hem is. B loopt woedend naar het districtshoofd, dat de zaak gaat onderzoeken. A komt met drie, vier getuigen bewijzen, dat hij den grond van Nebukadnezar zoo en zoo heeft gekocht, terwijl B met evenveel en even betrouwbare als onbetrouwbare ouden van dagen zijn bezitsrecht komt staven. De hoekoem-b̌̌sar ten einde raad, weet geen andere oplossing dan eene minnelijke schikking. Lukt die, dan bestaat nog de kans, dat een der partijen de gedane belofte niet nakomt en dan is men weer even ver. Komt er in het geheel geen schikking tot stand, dan wordt de klager naar den landraad verwezen, een advies, dat hij maar gewoonlijk in den wind slaat, omdat hij wel weet, dat hij als eischer het eerst met bewijzen moet aankomen. Zoo zijn er «beroemde perkara's, in Tondano, Rembokken, Ka'kas, Langoan, Tonsawang, Ratahan, die al menige districtshoofd, magistraat en landraadsvoorzitter tot wanhoop hebben gebracht en elk jaar weer met nieuwe complicatie's terugkomen. - In den oogsttijd gaat het al net zoo. Hoe tragi-comisch is het veel voorkomend tooneeltje, dat zich op betwiste sawahs afspeelt, wanneer twee partijen om strijd padiplanten snijden en weghalen! Een practisch hoofd liet gedurende den planttijd commissie's nagaan wie de sawahs beplantten! Zoodoende had hij later het wettig en overtuigend bewijs aan wien de oogst toekwam. Want als politie noch magistraat kan ingrijpen loopt het heftig getwist uit op ernstig misdrijf. 
Eene stap in de goede richting geeft het nieuwe Agrarisch Reglement in artikel 14 aan waarbij de mogelijkheid wordt geopend om overeenkomsten, ten doel hebbende vervreemding van grond in akten vast te stellen, verleden ten overstaan van het districtshoofd of andere personen. Het is jammer, dat het voorschrift niet gebiedend is, want nu zal het moeite kosten den kleinen man te overreden toch van elken koop en verkoop eene schriftelijke overeenkomst op te laten maken. Want de eenige oorzaak van de boven met voorbeelden uit het dagelijksch leven geillustreerde uiterst geringe rechtszekerheid is het gemis aan overtuigende, op schrift gestelde, bewijsstukken van overdracht van den grond.

Verpanding (gewoonlijk in de landstalen magade of maga'nde genoemd) is in de sawahstreken ook zeer veel in gebruik. Cijfers van de uitgestrektheid verpande sawahs zijn niet te geven, doch men zegt algemeen, dat bijv. in Tondano en Langoan verreweg het grootste gedeelte der bevloeide padivelden vepand zijn. - Wanneer van dit voor schuld verbinden van grond ook eene deugdelijke schriftelijke overeenkomst wordt opgemaakt, wat vrijwel algemeen in zwang is, dan is er geen gevaar voor latere bisbilles. Het weder verpanden van grond is ook een algemeene gewoonte, die toegelaten wordt, mits de eigenaar verklaart van die rechtshandeling af te weten en er mede in te stemmen. Meermalen wordt, helaas! die verklaring niet zwart op wit gesteld.

Het huren (meram Tb., Tt.) komt weinig voor, het geschiedt in sawahstreken in den vorm van deelbouw (toemojo' Td. matoeké $\mathrm{Tt}$.) ${ }^{1}$ ). De eigenaar geeft dan zijn grond (meestal sawah) aan een ander ter bewerking en beplanting; hij en de bewerker krijgen dan ieder de helft van de opbrengst. Is de grond een ladang met padi beplant, dan krijgt de bewerker twee derde deel van den oogst; wordt er mais op geplant dan is eene verdeeling in tweeën gewoonte.

$$
\text { Ma paloes. }{ }^{2} \text { ). }
$$

Met het toenemend belang eener deugdelijke voedselvoorziening heeft in de Minahassa het mapaloes in den laatsten tijd zeer

1) Si toemojo' = hij, die den grond ter beplanting en bewerking geeft.

-Si tinojo'an = hij, die den grond bewerkt en beplant.

2) Zie hierover ook: W. J. Beok, Mapaloes in Koloniale Studiën, Febr. 1922. 
de aandacht getrokken. Mapaloes (in het Tt. maando), een Tomboeloe'sch woord, dat ook in het Minahassisch Maleisch burgerrecht heeft verkregen, beteekent elkander vergelden. Het is dus een onderling en wederkeerig hulpbetoon bij allerlei werkzaamheden, voornamelijk die van landbouw, feesten en eetmalen, ook zelfs voor het bijeenzamelen van contanten voor ieder der leden; o.a. in Tondano brengt dan ieder lid telkens op bepaalde tijdstippen een klein bedrag bijeen, welk geld dan aan één der leden wordt gegeven. (mekekaja'an = elkander

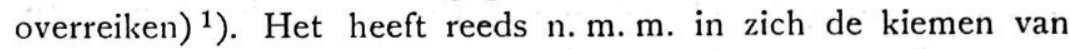
eene vereeniging. Het is een gezelschap van mannen en vrouwen ieder afzonderlijk of gemengd; jong en oud doen daaraan mee. Eén van hen neemt de leiding op zich, hij heet in het Tb., Td. en Ts. de soemesoeweng, waarschijnlijk oorspronkelijk degene, die de soeweng, de lont aanstak, die men vroeger gebruikte om den duur van den arbeid af te meten. Als belooning vour zijn arbeid krijgt hij een dubbel aandeel van het eten, dat gewoonlijk de bezitter van den akker waar men werkt, moet aanbieden. Dan is er nog een verdeeler van de spijzen, de mewētēng. Verder een toemetamor of loemeletele (Td.), si tamor (Tt.), de tamboer. Al heel vroeg in den ochtend dient hij de menschen met trommelslag te wekken; degenen, die dan meegaan naar de akkers staan op en als de trommelslager voor den tweeden keer gehoord wordt, moeten zij klaarstaan om zich bij het gezelschap aan te sluiten, meestal op eene vooraf afgesproken plaats. Op het werk moet hij de menschen weer roepen wanneer de tijd voor het middageten is aangebroken. Inplaats van een trom gebruikt men ook wel eens een schelp (semboeng, in nagenoeg alle talen) waarop men blaast of een gong (monongan) waarop men slaat. Tegenwoordig gaat men in Ratahan met muziek van fluiten en trom naar de akkers. Om nauwlettend toe te zien of ieder zijn werk naar behooren doet heeft men onder het gezelschap een oppasser, de mopangkol (Tt.).

Men heeft natuurlijk niet altijd zoo vele "bestuursleden ; is het gezelschap klein, dan is de verdeeling van bovenvermelden arbeid onnoodig. De leider kan dan alle werkzaamheden tegelijk verrichten.

1) Dit wederkeerig hulpbetoon was m. i. de oer-vorm van „dorpsdiensten”. 
De mapaloes-vereeniging kan vrijwillig door personen, die daartoe genegen zijn gevormd worden of van overheidswege (meestal van wege het districts- en negorijbestuur) georganiseerd worden.

ls het tijd geworden om de landbouwwerkzaamheden te beginnen, dan gaat iedere akkerbezitter eens rond bij zijne negorijgenooten om «een mapaloes, te vormen. Er ontstaan dan in elke negorij meerdere groepjes van personen, die zich het meest tot elkaar aangetrokken voelen. De verliefde jongeling vooral zorgt in het clubje te komen van zijn meisje om haar in haar arbeid te helpen en haar zijne liefde te uiten. Heeft zich eenmaal een groep gevormd, dan wordt in den loop van het plantjaar zelden nog iemand toegelaten. Ook wel sluiten zich de veldbezitters van elke dorpswijk (l o e k a r Tb., Tt.) aaneen; men noemt dat dan soemanaloeloekar. Soms vormen ook alleen opgeschoten jongens en meisjes, onder leiding van een paar ouderen een eigen gezelschap; men noemt dat in Tomohon réréo. Eigenaardig is de gewoonte aldaar, dat een meisje behalve hare eigen spade, ook die van een der jongens draagt. Men zegt, dat dit gebruik moet dateeren uit den ouden tijd, toen de man geen handen vrij had om de patjol te dragen, aangezien de tocht naar de bouwvelden niet zoo veilig was als thans en hij zich en zijne vrouw of verloofde tegen onverhoedsche aanvallen van snellers moest wapenen.

De manier van werken gaat op de volgende wijze. Op eene avondvergadering wordt vooraf door den soemesoeweng bepaald op wiens akker gewerkt zal worden en wat voor soort werk verricht moet worden. Den volgenden dag op het veld gekomen verdeelt hij, in Tondano, den te bewerken akker eerst in vakken en laat een ieder der leden een vak uitzoeken, hij zelf kiest het overgebleven en meestal dus het moeilijkste vak. Elders zag ik de menschen op de droge velden naast elkander werken, mannen en vrouwen vormen dan een «bonte rij» en het spreekt vanzelf, dat de jongens een plaatsje zoeken naast hunne meisjes.

Er zijn tegen het overtreden van de mapaloes-voorschriften strenge straffen bedreigd. Natuurlijk moeten de luie werkers het in de eerste plaats ontgelden, maar ook de laatkomers en degenen, die geen of verkeerde gereedschappen meenemen of brutaal en ongehoorzaam zijn. De luiaards krijgen allerlei 
spotliedjes te hooren wanneer het mapaloes-gezelschap weer de negorij binnenkomt, bijv. in Tondano: "é, si taka, si lengei

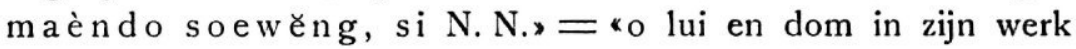
is N.N.», of: "linga linganaé, é kaloekar! tłnongko bentoean, si rai makaèndo soewěng si N. N. ngarana!, d. i. "hoort, hoort wijkgenooten! een groote maag bezit hij, maar werken kan hij niet, zijn naam is N. N.!» - Ook moet de luie voor straf zelf iets zingen, bijv. in Ratahan:

"Ja malawangké

Si kapala parènta wawingian.» $=$

«Ik overtrad het gebod

Van 't hoofd der mapaloes. ,

Als hij dit verscheidene malen alleen gezongen heeft, vallen de anderen in. Dit zijn echter niet de eenige straffen, die men uitdeelt. De overtreder kan ook beboet worden met het offeren van tabak, sirih, pinang en kalk aan ieder zijner medeleden, en zijn akker wordt het allerlaatst bewerkt. Eene andere straf is het onthouden van visch en vleesch bij de rijst, die de overtreder alleen afgezonderd van de anderen soms in den regen moet opeten of het toedienen van slagen met rotan of drie lidi's (palmbladnerven) tegen de kuiten. Eene zeer eigenaardige gewoonte zag ik in Ratahan. Een ieder kreeg van den mopangkol een tikje met een zweep, niemand ontkwam daaraan, ook het dorpshoofd, districtshoofd en zelfs de controleur niet. Deze laatsten moesten hunne hand ophouden en kregen een zacht tikje op de pols.

Om elkander aan te moedigen worden liedjes op eene inheemsche wijze gezongen. Een voorzanger, meestal de leider, begint te zingen, de anderen vallen dan in. De rythmische wijze waarop dit geschiedt is werkelijk een verlichting van het werk. Niet altijd zijn die liederen volgens Graafland (zie deel I blz. 159), van schoone strekking; er zijn er ook, die dubbelzinnige woordspelingen bevatten en zeer zinnelijk zijn. Ook heeft men ter aansporing het bakoekoe' (Mal.) of het koemoekoe' (Mal.), de vroegere strijdkreet in den stammenkrijg of op sneltochten, een typische - men zou haast zeggen - spottende schreeuw, dien men vaak in de Minahassa hoort.

Ieder lid wordt op zijne beurt geholpen. Is iemand om de eene of andere reden verhinderd te komen, dan moet hij een 
vervanger aanstellen. Ook gebeurt het wel eens, dat een mapaloes-gezelschap zich verhuurt aan een grootgrondbezitter. Men moet dan echter met het eigen werk gereed zijn (in het Tb. marawisan); het verdiende geld wordt onder de leden verdeeld of ook wel gebruikt voor een mapaloes-feestje, na afloop van de werkzaamheden.

Meestal moet de bezitter van den grond waarop gewerkt wordt het eten geven. Worden meerdere akkers op één dag bewerkt, dan zorgen de gezamenlijke eigenaren voor het eten. Tevoren wordt afgesproken wat er gegeten wordt; in enkele streken is men daar wel wat al te overdadig mee. Practischer lijkt de regeling om zelf het eten mede te nemen. Men noemt dat mesapoetan, omdat het eten gewikkeld (sapoet) is in een wokablad.

De mapaloes-gezelschappen werden vroeger met eerbied bejegend; kwam men terug van het werk, dan ging men naar het districtshoofd waar de leden op arak getracteerd werden (Ratahan). Als het gezelschap met de Hollandsche vlag er op uittrok, dan moest iedere voorbijganger, wie ook, voor de vlag groeten.

$\mathrm{Nu}$ de aanplant van voedingsgewassen in de laatste jaren met kracht is aangevat, is het mapaloes-instituut met zijne vele nuttige bepalingen herleefd. Zelfs zijn in Ratahan dank zij de krachtige leiding van het toenmalig districtshoofd Soepit in de vereenigingen meer bestendigheid gebracht. Elke negorij telt daar nu één of meer vereenigingen met eigen bestuur en eigen clubhuisje zelfs; die vereenigingen worden niet elk jaar ontbonden zooals bij de gewone mapaloes-gezelschappen geschiedt, maar hebben een duurzaam karakter. Als bestuursleden zijn gekozen personen, die geen plaats in het negorijbestuur hebben.

Indien in die richting onder verstandige leiding gewerkt wordt valt van dit specifiek Minahassisch instituut in de toekomst veel goeds te verwachten. 